Review

\title{
Bovine Colostrum: Its Constituents and Uses
}

\author{
Raymond John Playford ${ }^{1,2, *}$ and Michael James Weiser ${ }^{2}$ \\ 1 Barts and the London School of Medicine and Dentistry, Queen Mary University of London, \\ London E1 2AD, UK \\ 2 Department of R\&D, PanTheryx Inc., Boulder, CO 80301, USA; mike.weiser@pantheryx.com \\ * Correspondence: r.playford@qmul.ac.uk; Tel.: +44-2078827225
}

Citation: Playford, R.J.; Weiser, M.J. Bovine Colostrum: Its Constituents and Uses. Nutrients 2021, 13, 265. https://doi.org/10.3390/nu13010265

Received: 5 December 2020

Accepted: 14 January 2021

Published: 18 January 2021

Publisher's Note: MDPI stays neutral with regard to jurisdictional claims in published maps and institutional affiliations.

Copyright: (c) 2021 by the authors. Licensee MDPI, Basel, Switzerland. This article is an open access article distributed under the terms and conditions of the Creative Commons Attribution (CC BY) license (https:// creativecommons.org/licenses/by/ $4.0 /)$.

\begin{abstract}
Colostrum is the milk produced during the first few days after birth and contains high levels of immunoglobulins, antimicrobial peptides, and growth factors. Colostrum is important for supporting the growth, development, and immunologic defence of neonates. Colostrum is naturally packaged in a combination that helps prevent its destruction and maintain bioactivity until it reaches more distal gut regions and enables synergistic responses between protective and reparative agents present within it. Bovine colostrum been used for hundreds of years as a traditional or complementary therapy for a wide variety of ailments and in veterinary practice. Partly due to concerns about the side effects of standard Western medicines, there is interest in the use of natural-based products of which colostrum is a prime example. Numerous preclinical and clinical studies have demonstrated therapeutic benefits of bovine colostrum for a wide range of indications, including maintenance of wellbeing, treatment of medical conditions and for animal husbandry. Articles within this Special Issue of Nutrients cover the effects and use bovine colostrum and in this introductory article, we describe the main constituents, quality control and an overview of the use of bovine colostrum in health and disease.
\end{abstract}

Keywords: nutraceuticals; gut repair; growth factors; injury

\section{Introduction}

Bovine colostrum (BC) is the first milk produced after birth and is a rich natural source of macro- and micro-nutrients, immunoglobulins, and peptides with anti-microbial activity and growth factors. There is strong evidence that BC is important for the nutritional and immunological support, growth, and development of the new-born calf. It is produced by the milk industry and commercially sold to promote general health and immune support. There is also increasing evidence that BC may be of value for the treatment of a variety of medical conditions in children and adults [1,2] and as a supplement for athletes to aid exercise performance and recovery $[3,4]$. Its use is not restricted to humans, with evidence supporting a role for its use in animal husbandry and the health and wellbeing of large animals and domestic pets [5-9]. This article provides an overview of the main constituents of BC, variation in BC constituents over time following birth, and an introduction to its use in maintaining health and treating disease. Readers interested in detailed aspects of individual applications of BC are referred to the companion articles on related topics that will be published early in 2021: "BC and Gastrointestinal Disease" (Chandwe K. and Kelly M.P.); "Effect of BC on Immune Function" (Ghosh et al); "Use of BC in Sports Medicine" (Davison G.); and "Pediatric Value of BC" (Caitlin V., Burrin D., Sangild P.T.).

\section{Constituents of $\mathrm{BC}$}

BC contains similar nutrients to mature bovine milk, although the macronutrient profile and growth factor, immunoglobulins, and other immune factor content changes markedly from BC to mature milk. 


\subsection{Macronutrients and Micronutrients}

\subsubsection{Proteins and Peptides}

$\mathrm{BC}$ contains higher total protein content than mature milk, mainly due to higher levels of immunoglobulins and casein. Total protein concentration in BC constitutes about $15 \%$ of day one BC (weight/weight), falling to approximately $3 \%$ in mature milk. Protein constituents can be divided into two groups: whey proteins which are the soluble protein components, and caseins which are the insoluble proteins, with both components providing nutritional and bioactive properties. Casein is the predominant phosphoprotein that accounts for about $75 \%$ of proteins in cow milk and cheese, with $\alpha$ s1-casein being the predominant protein fraction of bovine milk [10]. Casein contains peptides with opioid-type activity that have been shown to decrease gastric emptying in rats [11]. Casein components have also been shown to affect immune activity when assessed using cell culture [12] and ex vivo methodologies [13]. Casein may also play a role in preserving the activity and aiding adsorption of other biologically active peptides by reducing their digestion by pancreatic enzymes, by means of functioning as a competitive substrate [14]. This action is similar to that reported for bovine trypsin inhibitor which protects IgGs, growth factors, and other biologically active proteins against proteolytic degradation within the gut. Bovine trypsin inhibitor is present in BC at about 100 times higher concentrations than mature milk [15]. Studies have demonstrated that the co-presence of casein partially protects epidermal growth factor (EGF) from digestion in humans [14], and that the stability and absorption of IGF-1 [16] is also improved. Casein also possesses other metabolic and protective effects including protective activity against experimental bacteraemia through increasing myelopoiesis [17]. Therefore, casein should not only be considered as an energy source but also as a factor that possesses immune-regulatory, antibacterial, and anti-inflammatory properties.

Whey proteins include immunoglobulins, lactoferrin, $\alpha$-lactalbumin, $\beta$-lactoglobulin, lactoperoxidase, glyco-macropeptide and several growth factors, including the EGFreceptor ligand betacellulin [18]. $\alpha$-lactalbumin is present in BC in high concentrations, comprising about one-quarter of the total protein content ( $40 \%$ of whey protein), with a high content of essential amino acids [19]. In addition to nutrient value, many whey proteins possess biological activity, some of which only become activated following exposure to acidification or partial digestion. Biological activities include influencing immune activity, reducing inflammation, and stimulating repair, e.g., $\alpha$-lactalbumin has been shown to reduce gastric injury caused by ethanol in rats [20], and $\alpha$-lactalbumin possesses antimicrobial and antitumor activity in addition to binding calcium and zinc ions [21]. In addition, hydrolysates of both casein and whey have been shown to interact with toll-like receptors involved in innate immune responses [22]. $\beta$-lactoglobulin comprises 162 amino acids (MW $18.4 \mathrm{kDa}$ ) and is a good source of essential amino acids but is also a major immunogen for subjects suffering from cow milk allergies. $\beta$-lactoglobulin is not present in human milk.

\subsubsection{Carbohydrates}

Carbohydrates in BC include lactose, oligosaccharides, glycolipids, glycoproteins, and nucleotide sugars. Lactose forms the predominant saccharide in BC, comprising approx. $2.5 \%$ [23], which is lower than in mature bovine milk or in human milk [24]. Lactose can provide galactose and glucose to the liver in support of glycogen synthesis and storage [25]. Dietary oligosaccharides are present at approx. $1 \mathrm{~g} / \mathrm{L}$ in BC, roughly double the levels in mature milk [26], and can act as prebiotics because many are not digested in the upper intestine, passing intact into the colon where they act as a metabolic substrate for colonic bacteria [27]. Oligosaccharides are divided into two broad classes, i.e., neutral, and acidic. Neutral oligosaccharides (also known as galacto-oligosaccharides) do not contain charged carbohydrate residues. In contrast, acidic oligosaccharides contain at least one negatively charged residue of $\mathrm{N}$-acetylneuraminic acid (sialic acid) [28]. Sialylated oligosaccharides comprise the majority of the oligosaccharides in BC, and approximately seven-fold higher 
levels of sialyl-oligosaccharides are found in $\mathrm{BC}$ as compared to mature milk $[26,29]$. The predominant oligosaccharides in BC are $3^{\prime}$-sialyllactose ( $\left.3^{\prime} \mathrm{SL}\right)$ and $6^{\prime}$-sialyllactose (6 $\left.6^{\prime} \mathrm{SL}\right)$, and in vitro work has demonstrated the ability of $3^{\prime} \mathrm{SL}$ to feed Bifidobacteria, which are important early colonisers of the human gut during infancy [30,31]. In addition to oligosaccharides, $\mathrm{BC}$ is rich in glycosylated proteins, which may have functional relevance by acting as prebiotics due to the saccharide component being cleaved by bacterial glycosidases, thereby influencing the gut microbiome. One of the predominant glycoproteins in $\mathrm{BC}$ is bovine glycomacropeptide (GMP) which has different glycosylated forms and is created via K-casein proteolysis during digestion. Bovine GMP has bifidogenic abilities, as shown by its concentration-dependent growth promotion of the Bifidobacterium longum subspecies infantis [32].

\subsubsection{Fats and Lipids}

BC contains approx. $7 \%$ fat, predominantly comprising milk fat globules. The lipid fraction contains multiple components of potential health relevance, including $\omega-3$ and $\omega-6$ polyunsaturated fatty acids, conjugated linoleic acid, short chain fatty acids, gangliosides, and phospholipids. Fatty acid constituents of BC are approximately $65-75 \%$ saturated, $24-28 \%$ monounsaturated and $4-5 \%$ polyunsaturated $[33,34]$, and the predominant fatty acids are palmitic and oleic, accounting for $40 \%$ and $21 \%$ of total fatty acids, respectively [34]. The fat component of $\mathrm{BC}$ is often removed from commercial preparations to aid stability and processing; however, it is not biologically inert. For example, gangliosides and phospholipids are polar lipids found in the milk fat globule membrane and are involved in multiple functions such as neuronal development, binding of pathogens, and immune activation. For an excellent review on the biological effects of phospholipids in milk and BC, see Verardo et al. [35]. Additionally, evidence continues to build for the importance of palmitate in early life nutrition [36,37], and oleic acid has been linked to benefits ranging from immunomodulation to cardiovascular health [38].

\subsubsection{Vitamins and Minerals}

BC contains fat-soluble (A, D and E) and water-soluble (B series) vitamins, which may be relevant for many metabolic processes including bone growth and antioxidant activity. Vitamin D has also been implicated in supporting immune system function and mental health [39]. Most vitamins are typically higher in concentration within $B C$ as compared to mature milk, especially vitamins $\mathrm{B}_{2}, \mathrm{~B}_{12}, \mathrm{E}$, and D (Table 1 ). Compared to mature milk, $\mathrm{BC}$ is also rich in several essential minerals including calcium, copper, iron, zinc, magnesium, manganese, and phosphorus, (see $[15,23,40])$.

Table 1. Concentrations of select macronutrients, micronutrients, immunoglobulins, and general antimicrobial peptides present in bovine colostrum (BC) and mature milk.

\begin{tabular}{ccc}
\hline Component & BC & Mature Milk \\
\hline Total solids $(\%)$ & $24-28$ & 12.9 \\
Fat $(\%)$ & $6-7$ & $3.6-4.0$ \\
Protein $(\%)$ & $14-16$ & $3.1-3.2$ \\
Casein $(\%)$ & 4.8 & $2.5-2.6$ \\
Albumin $(\%)$ & 6.0 & $0.4-0.5$ \\
Total immunoglobulin & $42-90$ & $0.4-0.9$ \\
(mg/mL) & $2-3$ & $4.7-5.0$ \\
Lactose $(\%)$ & & \\
Minerals & $2.6-4.7$ & $1.2-1.3$ \\
Calcium $(\mathrm{g} / \mathrm{kg})$ & 4.5 & $0.9-1.2$ \\
Phosphorus $(\mathrm{g} / \mathrm{kg})$ & $1.4-2.8$ & $1.5-1.7$ \\
Potassium $(\mathrm{g} / \mathrm{kg})$ & $0.7-1.1$ & 0.4 \\
Sodium $(\mathrm{g} / \mathrm{kg})$ & $0.4-0.7$ & 0.1 \\
Magnesium $(\mathrm{g} / \mathrm{kg})$ & $11.6-38.1$ & $3.0-6.0$ \\
Zinc $(\mathrm{mg} / \mathrm{kg})$ & &
\end{tabular}


Table 1. Cont.

\begin{tabular}{ccc}
\hline Component & BC & Mature Milk \\
\hline Vitamins & & \\
Thiamin $(\mathrm{B} 1)(\mu \mathrm{g} / \mathrm{mL})$ & $0.58-0.90$ & $0.4-0.5$ \\
Riboflavin $(\mathrm{B} 2)(\mu \mathrm{g} / \mathrm{mL})$ & $4.55-4.83$ & $1.5-1.7$ \\
Niacin $(\mathrm{B} 3)(\mu \mathrm{g} / \mathrm{mL})$ & $0.34-0.96$ & $0.8-0.9$ \\
Cobalamin $(\mathrm{B} 12)(\mu \mathrm{g} / \mathrm{mL})$ & $0.05-0.60$ & $0.004-0.006$ \\
Vitamin A $(\mu \mathrm{g} / 100 \mathrm{~mL})$ & 25 & 34 \\
Vitamin D $(\mathrm{IU} / \mathrm{g}$ fat) & $0.89-1.81$ & 0.41 \\
Tocopherol $(\mathrm{E})(\mu \mathrm{g} / \mathrm{g})$ & $2.92-5.63$ & 0.06 \\
\hline Immunoglobulins & & \\
IgG1 $(\mathrm{g} / \mathrm{L})$ & $34.0-87.0$ & $0.31-0.40$ \\
IgG2 $(\mathrm{g} / \mathrm{L})$ & $1.6-6.0$ & $0.03-0.08$ \\
IgA $(\mathrm{g} / \mathrm{L})$ & $3.2-6.2$ & $0.04-0.06$ \\
IgM $(\mathrm{g} / \mathrm{L})$ & $3.7-6.1$ & $0.03-0.06$ \\
\hline Antimicrobials & & \\
Lactoferrin $(\mathrm{g} / \mathrm{L})$ & $1.5-5$ & $0.02-0.75$ \\
Lactoperoxidase $(\mathrm{mg} / \mathrm{L})$ & $11-45$ & $13-30$ \\
Lysozyme $(\mathrm{mg} / \mathrm{L})$ & $0.14-0.7$ & $0.07-0.6$ \\
\hline Ranges are shown where available. Values were obtained from refs $[15,23,40-45]$ &
\end{tabular}

Ranges are shown where available. Values were obtained from refs [15,23,40-45].

\subsection{Bioactive Components}

$\mathrm{BC}$ contains multiple components that influence the growth, development, and immune function of the suckling neonate, and cover a wide range of molecular weights (Figure 1). The major constituents of BC influencing these activities are discussed in the following sections.

\subsubsection{Antimicrobial Factors Immunoglobulins}

In mammals, immunoglobulins are important in passing passive immunity from mother to offspring. In $\mathrm{BC}$, the major immunoglobulin is IgG, with a concentration of $30-87 \mathrm{~g} \mathrm{~L}^{-1}$, contributing approx. $80-90 \%$ of the total IgGs, with smaller amounts of IgA, IgD, IgE, and IgM being present (Table 1) [15]. In contrast to humans, where immunoglobulins can traverse the placental barrier, this does not occur in cows, and the calf's sole natural source of immunoglobulins is from the consumption of BC. Immunoglobulins comprise a variable region that determine antigen binding specificity and a constant $\mathrm{FC}$ region. Once an antigen is bound, immune complexes are formed, and the Fc region interacts with multiple immune effector cells, such as phagocytes, NK cells, dendritic cells and CD4+ T lymphocytes through binding to their Fc receptors. Bovine immunoglobulins can help prevent pathogen binding to host cells, present pathogens to macrophages for destruction, stimulate $\mathrm{T}$ cell and $\mathrm{B}$ cell immune activation, modify intestinal microflora, and induce local immunoglobulin A production [46]. IgG can, therefore, provide both passive immunity and modulate the adaptive and innate immune systems. Readers interested in the details of immune effects of BC and signalling pathways involved in microbe destruction and cytokine/antibody production, including IgFc interaction with effector cells, are referred to the upcoming article in this series on the "Immunological Effects of BC" by Ghosh S. et al. [46].

In addition to normal IgG constituents, specific vaccination of cows against human or bovine pathogens (hyper-immunisation) results in the production of neutralizing antibodies that show benefits for preventing and treating infections, resulting in increased weight gain in clinical and veterinary situations. Examples include preventing and treating enteropathic infections by Escherichia coli [47] or rotavirus [48]. Similarly, using a tooth surface model, a concentrate of hyper-immune milk was shown to prevent adherence of Candida albicans [49], and a hyperimmune BC preparation reduced dental plaque [50]. Although the use of purified specific antibodies from serum or milk appears to have value 
for infectious diseases [51], there may be additional benefits in using whole hyperimmune $\mathrm{BC}$ because it also enhances the repair process mediated through its growth factor constituents in addition to enhancing eradication of infections via its nonspecific antibacterial components.
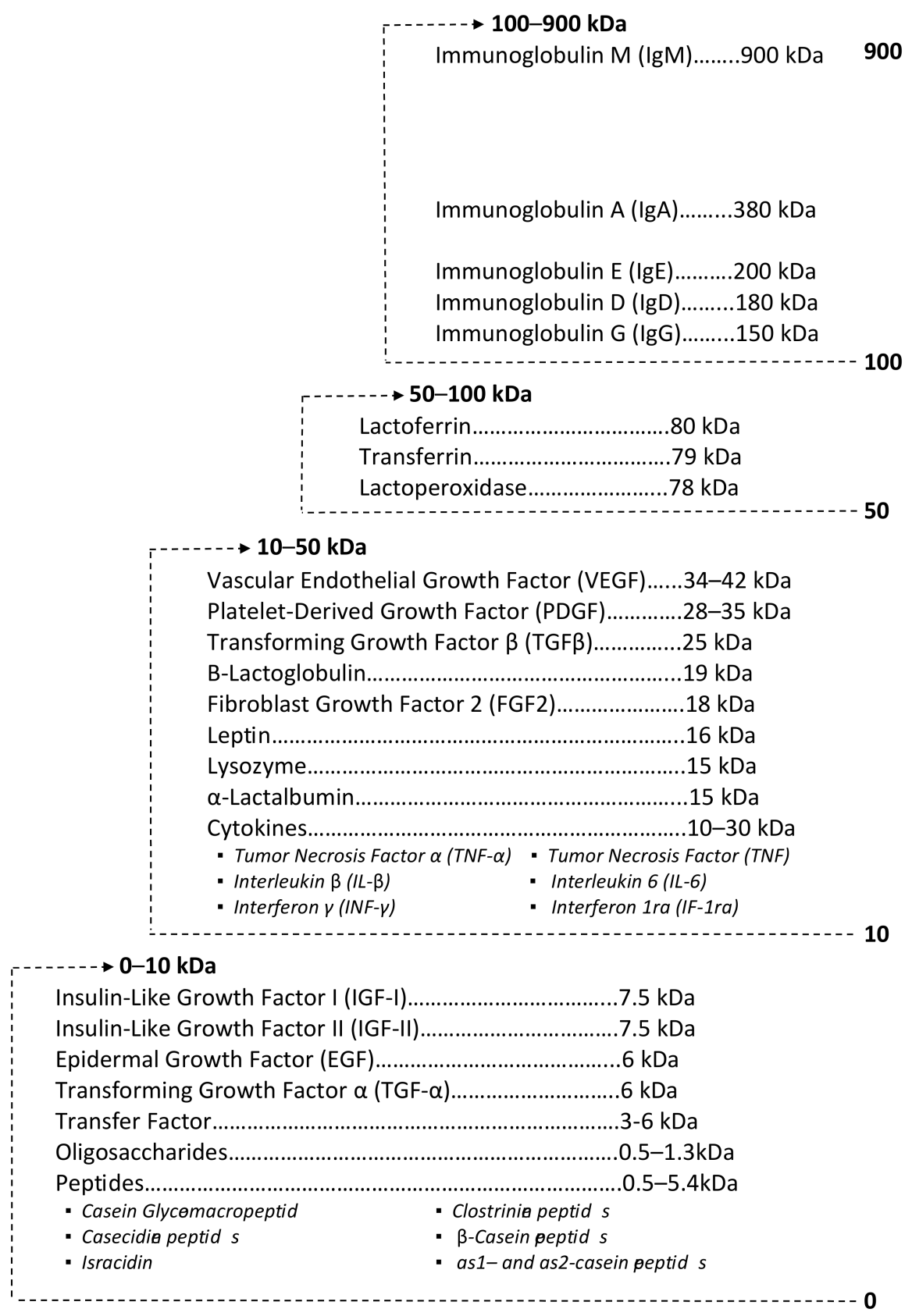

Figure 1. Molecular weight distribution for select components of Bovine colostrum (BC).

Other Antimicrobials

While immunoglobulins undoubtedly play an important role in preventing and resolving microbial infections, multiple other components of $\mathrm{BC}$ are also involved, as shown in Figure 2. Bioactive oligosaccharides present in BC may help protect against pathogens by acting as a prebiotic, i.e., stimulating growth of beneficial bacteria in the gut lumen. In addition, they may function as competitive inhibitors against toxigenic bacteria for binding sites on gut epithelial cells by mimicking epithelial cell surface carbohydrates [15,52]. 
For example, in vitro studies have shown that bovine milk oligosaccharides inhibit the adhesion of E. coli, Salmonella, C. sakazakii, and H. pylori [53].

\section{BC components modulating immune response}

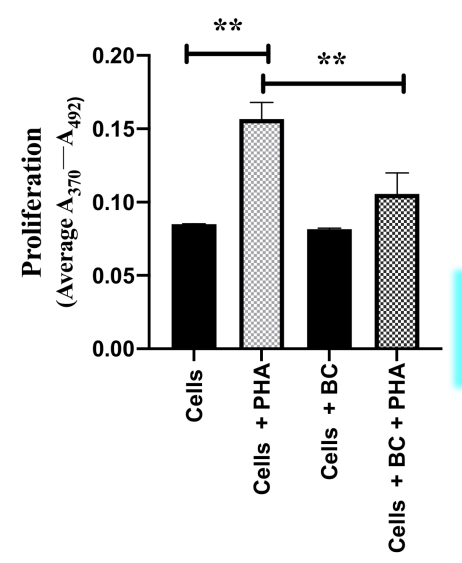

A

\section{$\mathrm{BC}$ components targeting the immune system and microbial threats}

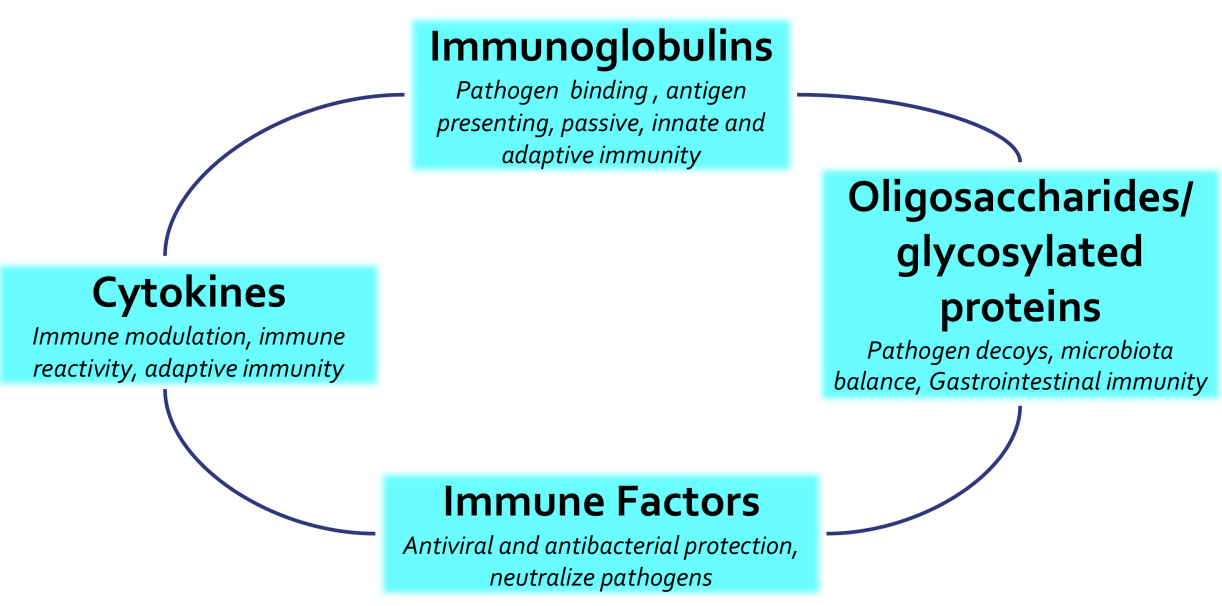

B

Figure 2. Influence of BC on immune function. (A) BC modulates immune response. BC reduced proliferation (BRDU incorporation) of human lymphocytes ( $n=5$ healthy subjects) stimulated by phytohemagglutination (PHA). PHA increased proliferation two-fold but was markedly truncated by BC $(1 \mathrm{mg} / \mathrm{mL})$. ${ }^{* *}$ indicates $p<0.01$ versus comparator. Data were kindly provided by Drs P Lalor and L Sheriff, University of Birmingham. (B) Multiple constituents of BC are involved in modulating the immune system and targeting microbes and other threats.

Lactoperoxidase is an antimicrobial glycoprotein and member of the heme peroxidase family of enzymes that inhibits bacterial metabolism. Lactoperoxidase is an effective antimicrobial agent and is toxic to multiple Gram-positive and Gram-negative bacteria [54], through actions including the production of reactive oxygen species. These oxidative species can interact with certain amino acids in microbial proteins, leading to the inhibition of microbial metabolism and replication. Lactoperoxidase is added as a preservative in a variety of food products, cosmetics, and ophthalmic and oral hygiene products.

Lysozyme possesses antibacterial activity causing cell lysis of Gram-negative bacteria, as well as inhibiting the growth of Gram-positive bacteria $[55,56]$. Lactoferrin also enhances lysozyme antibacterial activity against E. coli [43]. Evidence in support of the value of lysozyme in $\mathrm{BC}$ also includes the finding that if lysozyme-deficit infant formulae is used, rather than one containing lysozyme, it results in a three-fold increase in diarrhoeal disease [57].

Lactoferrin is an iron binding glycoprotein $(80 \mathrm{kDa})$ present in human colostrum and $\mathrm{BC}$, although levels in $\mathrm{BC}$ are only about $10 \%$ of human values $[58,59]$. Lactoferrin induces multiple effects, including enhancing iron absorption as well as possessing antimicrobial activity $[60,61]$, binding lipopolysaccharide, immune-modulating, and stimulating growth of intestinal epithelial cells and fibroblasts [62]. These findings suggest lactoferrin in BC may be relevant for the regulation of gut growth in neonates. Lactoferrin administration has been shown to reduce mortality and to increase growth in calves [55], reduce infections of the respiratory tract in bottle-fed infant humans [63], and reduce Giardia lamblia colonisation in children [64]. It also possesses immune modulatory activity, as demonstrated by reducing pollen antigen-induced allergic airway inflammation in a mouse model of asthma [65]. A Cochrane review also suggested that orally ingested lactoferrin may have value for reducing the risk of infections in addition to preventing the onset of necrotizing 
enterocolitis in preterm infants [66]. The concentrations of lactoperoxidase, lysozyme and lactoferrin in BC and mature milk are shown in Table 1.

\subsubsection{Cytokines and Immune Regulators \\ Cytokines}

Immune defence is mediated through a combination of innate and adaptive processes. BC contains multiple constituents that may influence both of these pathways. The innate immune system is the first line of defence and protects against enteric infectious pathogens by detecting and eliminating them through cellular and molecular processes. These responses are subsequently progressed via the adaptive immune system, mediated through $B$ and $\mathrm{T}$ cells. BC contains both specific immune factors (e.g., IgGs) and non-specific immune modulatory and antimicrobial factors (e.g., lactoferrin), with each component potentially having relevance for immune modulation. There is now extensive data showing that $\mathrm{BC}$ may have value for preventing and treating microbial infections, e.g., [67], working via the hosts immune function [68], in addition to attacking the microbe itself. As an example, volunteers given $\mathrm{BC}$ at the same time as receiving attenuated oral Salmonella typhi Ty21a vaccine produced increased levels of circulating specific IgA compared to controls who did not receive $\mathrm{BC}$ [69].

Cytokines are peptides/proteins involved in immune activation and recruitment, cellular signalling, and pathogen recognition. Cytokines are not usually involved in normal cellular homeostasis, but become relevant at times of stress, inflammation, or injury [70], stimulating actions such as differentiation, chemotaxis and protein synthesis. They regulate expression of a wide range of immune responses towards pathogens, influencing which types of immune cells are recruited for both adaptive and innate immune responses. $\mathrm{BC}$ and milk contain many cytokines, including $\mathrm{TNF} \alpha$, granulocyte, macrophage, and GMCSF and interleukin (IL) 1 $\beta$, IL-6, IL-10 [55]. Cytokines likely play a role in modulating immunologic development in new-born and infants, working in combination with ingested maternal immunoglobulins and the nonspecific antibacterial factors in BC (Figure 2). Importantly, cytokines are not solely involved with stimulating inflammation, with some cytokines, such as IL-8, stimulating cell migration of colonic cell lines [71], and IL-10 being involved in preventing excess inflammatory response [72]. In support of the idea that BC dampens excess immune reactivity, a study using human colonic carcinoma cells (HT-29) showed that treatment with BC inhibited IL-1 $\beta$-induced IL-8 expression, suppressed IL$1 \beta$-induced nuclear factor kappa beta $(\mathrm{NF} \kappa \beta)$ activation, and inhibited the degradation of inhibitor protein $N F \kappa \beta$ [73], suggesting that $B C$ may protect against intestinal inflammation by inhibiting the NFK $\beta$ pathway. Similarly, the presence of $B C$ markedly reduces the phytohemagglutination (PHA)-induced proliferation of human peripheral lymphocytes (Figure 2A, previously unpublished data).

Although often considered as distinct, cytokines and growth factors have overlapping activities, e.g., the "cytokine" IL-8 stimulates the migration of human colonic epithelial cells [74], an action normally attributed to growth factors. Furthermore, there appears to be "cross-talk" between cytokines and growth factors in mediating their actions. For more detailed information on the effects of $\mathrm{BC}$ on immune function, readers are referred to the upcoming article in this Special Issue by Ghosh S. et al.

\section{Other Immune Regulators}

Fresh BC contains maternal leukocytes, such as B and T lymphocytes, macrophages, and neutrophils, in addition to epithelial cells [75]. These leukocytes protect the body against enteric pathogens by acting directly on the microbe, in addition to stimulating a local immune response, such as the production of cytokines, IgG, and antimicrobial factors [45]. The usual purification and preparation of BC for human use removes these cells from the final product. 
MicroRNA elements with immune-regulating potential are also present in BC. These components are present in micro vesicles that are relatively stable during passage through the gastrointestinal tract and may influence lymphoid cell function within the intestine [76].

Colostrinin (also known as proline-rich polypeptide or PRP) is a naturally occurring mixture of proline-rich polypeptides derived from BC, which has been shown to help combat excessive inflammatory responses. The amino acid compositions of Colostrinin from ovine, bovine, and human colostrum are similar [77]. Colostrinin is not completely chemically defined, but comprises a mixture of at least 32 peptides with MWts 0.5 to $3 \mathrm{kDa}$ [78], mainly derived from partial proteolysis of $\beta$-casein and $a \beta$-casein. Colostrinin/PRPs help regulate the production of cytokines and may also inhibit the production of damaging reactive oxygen species [79]. Evidence in support of these actions include the findings that Colostrinin prevents allergic inflammation due to common and outdoor allergens in a murine allergic airway inflammation model [80], and immunocompromised rats infected with enterotoxigenic E. coli had reduced endotoxin levels and infected lymph nodes when treated with Colostrinin [81].

\subsubsection{Growth Factors}

BC contains multiple components that stimulate growth, differentiation, and development. Although growth factors are normally considered to be peptides or small proteins, several other factors present in BC induce similar effects, although not usually acting via a classical receptor ligand interaction. These include glutamine, nucleotides, and polyamines and are sometimes termed preferred substrates, as opposed to growth factors. Nevertheless, these molecules play an important role in maintaining gut growth and immune activity, acting either directly or through altering the intestinal flora.

Over twenty different peptide growth factors have been described in BC, and the main ones are described in the following section. Although described individually, it is important to note that their functions are interrelated; cells are exposed to multiple factors at any one time and may result in additive or even synergistic responses. This was demonstrated by the finding that when bovine lactoferrin and EGF were added together to rat intestinal IEC-18 cells, it resulted in a synergistic growth response [82].

Growth factor constituents of colostrum vary markedly across species, for example, EGF content of human colostrum is much higher than BC. Even within species, major changes occur during the first few days post-birthing-some studies have shown marked reductions in multiple growth factor constituents of BC during the first 48-72 h post-calving (Figure 3 [83]).

\section{Insulin-Like Growth Factors (Somatomedins) and Their Binding Process}

IGF-I and IGF-II promote cell proliferation and differentiation [84], and there is $100 \%$ sequence homology between the bovine and human IGFs. They have structural similarity to pro-insulin and, when administered at high concentrations, IGFs can exert insulinlike effects. Endogenous IGF is mainly produced by the liver [85]. The concentration of IGF-I within BC is much higher than that found in human colostrum $\left(500 \mathrm{mg} \mathrm{L}^{-1}\right.$ versus $18 \mathrm{mg} \mathrm{L}^{-1}$ ) [86,87], with IGF-I levels falling to approx. $10 \mathrm{mg} \mathrm{L}^{-1}$ in mature bovine milk [88]. IGF-I and-II have been shown to survive exposure to both acid and heat, and it is therefore likely that they remain biologically intact during commercial milk processing as well as during passage through the stomach [89]. IGF-I is an anabolic factor promoting protein accumulation [90], and is probably involved in mediating the growth-promoting actions of growth hormone. 


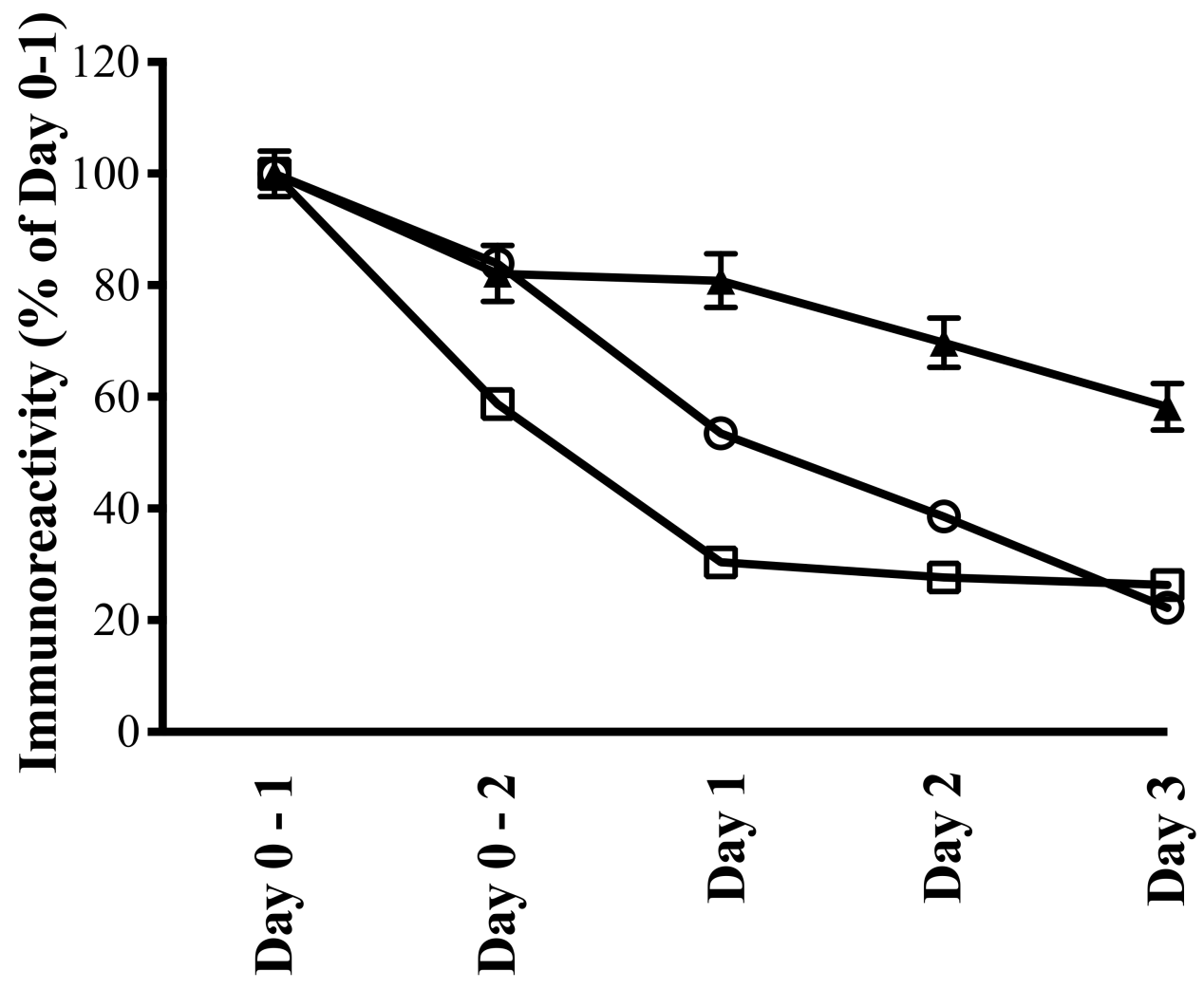

Figure 3. Change in IgG and some growth factor constituents within BC during the first few days post-calving. $\mathrm{BC}$ was collected at the first and second milking on day 0 , and daily for the following 3 days from 6 cows post-calving, i.e., Day 0-1 and 0-2 samples were both collected on the first day after calving. Samples were analysed for IgG and growth factor concentrations using commercial

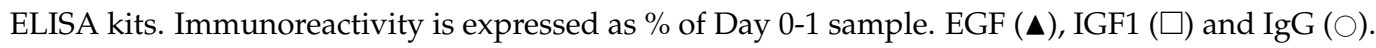
Results are expressed as mean \pm SEM of 6 animals per time point, with each sample measured in triplicate. The concentrations of all constituents shown were significantly reduced in each subsequent collection, $p<0.01$ vs. their Day 0-1 value. Adapted from [83].

Within BC and human colostrum, IGFs exist in both bound and free forms. Free IGF levels vary during the perinatal period, with the majority of IGF-I in BC being present in the free form, whereas the reverse is true in the antepartum period and in mature milk [91]. Six IGF binding proteins (IGFBPs) have been identified, and one of their functions is to act as carrier proteins, reducing the proteolysis of IGF during its transit through the intestine. Importantly, modulation of IGF-I activity can be mediated by changes in the relative percentage of IGFs present in the bound state; proliferative activity is only seen in the unbound IGFs. In addition, some studies suggest that there is cross-talk between the gut microbiome and circulating IGF levels [92].

The high concentrations of IGFs in BC suggest that they may be important in mediating local gut anabolic-reparative effects. There has been debate however, regarding whether IGFs within BC are absorbed intact, raising the theoretical concern that this might increase the risk of prostate cancer, because prostate cancer cells may express IGF-I receptors. However, the pathophysiological situation is more complicated, because administration of IGF-I to noncancerous prostate cells increases differentiation [93]. It is therefore reassuring that one study measuring IGF levels in subjects taking high doses of BC ( $40 \mathrm{~g} /$ day for several months) showed no significant increase in plasma IGF levels [94].

Epidermal Growth Factor Receptor Ligand Family

This family of peptides all bind the EGF receptor (also known as the c-erb1 receptor), and include EGF, TGF- $\alpha$, betacellulin, mammary-derived growth factor II, and human milk growth factor III. Other related members of this EGF-receptor binding family that are not 
present in significant concentrations in BC are heparin binding EGF and amphiregulin (for a detailed review of this family of peptides see [95]).

\section{Epidermal Growth Factor}

EGF contains 53 amino acids and is produced by the salivary glands and Brunner's glands within the duodenum. EGF is present in human colostrum $\left(200 \mathrm{mg} \mathrm{L}^{-1}\right)$ and milk (30-50 $\left.\mathrm{mg} \mathrm{L}^{-1}\right)$, as well as in many other species. Studies examining the stability of milk-borne EGF by incubating with gastric juice from preterm infants suggests that it remains intact [96], whereas adult gastric juice causes a major reduction in the bioactivity of EGF due to it being cleaved to an EGF1-49 form [97]. The relative stability of EGF within the small intestine is dependent on whether additional food proteins are present. In fasting conditions, it is rapidly destroyed by pancreatic proteolytic enzymes, whereas if ingested food proteins such as casein or trypsin inhibitors are also present, the EGF is preserved [14]. The EGF receptor is restricted to basolateral membranes and not present on apical (luminal) surfaces of the gut [98]. This suggests that orally ingested EGF-receptor ligands would not affect the normal adult intact gastrointestinal tract but would be immediately available to stimulate repair at sites of injury where the basolateral receptor becomes available, acting as a "luminal surveillance peptide", immediately available to stimulate the repair process at sites of injury [99].

It is important that distinction between the physiological effects of oral EGF-R ligands in adults and neonates is made. The presence of EGF as a constituent of human colostrum or in $\mathrm{BC}$ within the gut lumen may be able to access basolateral receptors within the immature neonatal gut [100] due to its increased permeability, and could, therefore, help prevent bacterial translocation [101] and stimulate gut growth in suckling neonates. Interestingly, an alternative approach to locally deliver EGF and reduce its proteolytic digestion involved administering E. coli bacteria that had been genetically modified to produce human EGF. This was seen to be beneficial in reducing dextran sodium sulphate (DSS)-induced colitis in mice [102].

\section{Transforming Growth Factor $\alpha$}

TGF- $\alpha$ concentrations in human colostrum and milk are much lower concentrations (2.2-7.2 $\mathrm{mg} \mathrm{L}^{-1}$ ) than EGF [103]. TGF- $\alpha$ contains 50 amino acid residues and is produced by mucosa of the entire length of the gut [104]. Systemic administration of TGF- $\alpha$ has multiple effects including reducing gastric acid production, increasing gastric mucus production, and stimulating gut growth and repair [105]. However, some of these effects are probably pharmacological, rather than physiological, because TGF- $\alpha$ expression in the small intestine is restricted to the superficial (non-proliferating) areas, suggesting that its physiological function could be related to cellular migration and differentiation as opposed to cell growth.

\section{Transforming Growth Factor $\beta$ Family}

There are 35 isoforms of TGF- $\beta$, and this group of peptides have a distinct structure from that of TGF- $\alpha$. In most proliferation assays, the TGF- $\beta$ family inhibits proliferation, rather than stimulating it. They are mainly expressed in the superficial zones of the normal gastrointestinal tract. TGF- $\beta$ has several functions, such as acting as a chemoattractant for neutrophils and increasing epithelial cell migration at the edges of wounds [106]. TGF- $\beta$ is therefore probably important in stimulating the initial stages of repair, where surviving cells at the wound edge migrate over the damaged region to re-establish a continuous epithelial layer. Concentrations of TGF- $\beta$ within BC are high (20-40 $\left.\mathrm{mg} \mathrm{L}^{-1}\right)$, and although they are lower in mature milk, they still are at relatively high levels $\left(1-2 \mathrm{mg} \mathrm{L}^{-1}\right)$. These levels are sufficient to protect rat stomachs against indomethacin-induced injury [107], suggesting that TGF- $\beta$ in BC (and human colostrum) may be important in maintaining gastrointestinal integrity in suckling neonates [108]. For an excellent review on the roles of TGF- $\beta$ on gut, skin and lung integrity see [109]. 


\section{Platelet-Derived Growth Factor}

As the name suggests, platelet-derived growth factor (PDGF) was initially identified in platelets, however it is also produced and secreted by macrophages. PDGF is acidstable, consisting of two disulphide-linked polypeptides: chain A $(14 \mathrm{kDa})$ and chain $\mathrm{B}$ $(17 \mathrm{kDa})$. The dimer exists in three isoforms $(\mathrm{AA}, \mathrm{AB}$, and $\mathrm{BB})$ that bind tyrosine kinasetype receptors. PDGF stimulates proliferation of a variety of cells including fibroblasts and arterial smooth muscle cells, and oral administration of PDGF enhances ulcer healing in animal models. Although human colostrum and BC contain PDGF, the majority of PDGF-like proliferative activity in BC is actually due to bovine colostral growth factor, which shares sequence homology with PDGF [110-112].

\section{Vascular Endothelial Growth Factor}

Vascular endothelial growth factor (VEGF) is a heparin-binding glycoprotein and is present as a homodimer (Mwt 34-42 kDa). VEGF exhibits many actions of potential pathophysiological significance, including stimulating proliferation and new vessel formation and vascular permeability-enhancing activity [113]. VEGF is present in human breast milk at about $75 \mathrm{mg} \mathrm{L}^{-1}$ during the initial seven days of lactation, falling to about $25 \mathrm{mg} \mathrm{L}^{-1}$ in the following week [114]. Due to its angiogenic activity, the VEGF content of BC may have value in enhancing local vascular supply in conditions such as peptic ulceration.

\section{Milk Fat Globule-Epidermal Growth Factor 8 (MFG-E8)}

Milk fat globule-epidermal growth factor 8 (MFG-E8) is a secreted protein initially identified as a critical component of the milk fat globule. It is present in BC in high concentrations and may influence the immune and repair response of the suckling neonate [115]. MFG-E8 enhances the removal of damaged and apoptotic cells by phagocytosis, induction of VEGF-mediated new vessel formation, and enhancement of mucosal healing [116].

\subsubsection{Hormones}

BC contains multiple hormones, including prolactin, somatostatin, oxytocin, luteinizing hormone-releasing hormone, thyroid-stimulating hormone, thyroxine, calcitonin, oestrogen, and progesterone. It is probable that at least some of these factors influence development of the suckling neonates [117], due to passage of the hormones from the gut into the circulation. This is less likely to be relevant in adults, because the reduced permeability of the adult gut restricts the passage of most of these factors, as demonstrated by the finding that ingestion of large amounts of BC failed to increase plasma IGF-1 levels in normal adults [94]. However, it remains possible that systemic absorption could have relevance in disease states where gut permeability may be increased.

\section{Growth Hormone and Its Releasing Factor}

Growth hormone $(\mathrm{GH})$, its releasing factor (GHRF), and binding protein are all present in human colostrum, BC, and milk [118]. Suckling neonates have high circulating levels of $\mathrm{GH}$, probably due to the consumption and absorption of GH as well as GHRF, which causes the neonate to produce endogenous GH from the pituitary gland [119]. The proliferative effects of GH are mediated partly by GH itself and partly due to the stimulation of IGF-1 production and secretion [120]. Systemic GH probably plays a role in gut growth and function, with GH receptors present throughout the human gastrointestinal tract [121]. In addition, studies have suggested that there is cross-talk between GH, IGF-1, and the gut microbiome [122]. However, the effect of GH within the gut lumen (as occurs when ingesting $\mathrm{BC}$ ) is uncertain, because stimulation would probably only occur if the $\mathrm{GH}$ receptors were present on the apical surfaces of the enterocytes, which is currently unknown.

\section{Leptin}

Leptin contains 167 amino acid residues and has an MWt of 16-kDa. This hormone is important in controlling energy intake and expenditure, through actions on appetite 
and metabolism. Leptin acts on hypothalamic receptors in the brain, inhibiting appetite by counteracting actions of the feeding stimulators neuropeptide $\mathrm{Y}$ and anandamide and by stimulating synthesis of the appetite suppressant $\alpha$-melanocyte-stimulating hormones. Although leptin is only present in BC at low concentrations (13.9 $\mathrm{mg} \mathrm{L}^{-1}$ [123]), a study in a diabetic mouse (ob/ob) strain showed that only very low concentrations of leptin are required to exert effects on glucose metabolism [124].

\section{Assessment of BC for Human Use}

$\mathrm{BC}$ is widely available for human and animal consumption from health food stores and via the internet. $\mathrm{BC}$ is normally collected and frozen on the individual farms and shipped frozen to central processing facilities, where it undergoes pasteurisation, optional defatting and the removal of lactose, then spray- or freeze-drying to a powder. This powder product may then be sold in powder form or subsequently incorporated into dietary supplement formats such as sachets, capsules, chewable tablets, and soft chews. There are some food categories where BC has been, or could be, utilised as a functional ingredient, such as cheeses, jellies, yoghurts, ice cream, nutritional bars, milk powdered beverages, and ready-to-drink beverages.

$\mathrm{BC}$ routinely undergoes high temperature short duration pasteurisation (usually about 15 seconds at $72{ }^{\circ} \mathrm{C}$ ) or alternatively batch pasteurisation, where the $\mathrm{BC}$ is heated to between 60 and $63{ }^{\circ} \mathrm{C}$ for anywhere between $30 \mathrm{~min}$ and $60 \mathrm{~min}$ [125]. Once dried, BC powder is normally recommended to be stored at room temperature, and most commercially available powders have at least one-year shelf life, in some cases longer.

The majority of BC for human use and for clinical trials is either complete BC (containing the fat component) powder or the defatted (skimmed) powder. Other preparations include the sterile filtering of raw BC, BC which has had subfractions removed (such as casein), or a combination of selective removal of constituents such as casein and lactalbumin, combined with the enrichment of factors such as immunoglobulins and growth factors, e.g., as used in [2]. It is, therefore, important that the form of BC is noted, in addition to the dosage being used.

IgG content of BC is considered a surrogate marker of quality, with concentration $>50 \mathrm{~g} / \mathrm{L}$ in fresh BC generally being considered acceptable [126,127]. IgG content of BC will vary according to the breed of cattle, age of the animals, and other factors including the feeding regimen, but one of the most important factors is the timing of the BC collection post-calving, with IgG levels (along with many of the growth factor constituents) falling rapidly on day 2-3 after calving (Figure 3) [83]. Although there is no formal definition regarding how many days following calving the product can be classified as colostrum rather than milk, it is generally accepted BC should only be considered as such up to day 3 post-calving [128]. However, some producers do market "late colostrum" which is collected between days 5-7 post-calving.

In parallel with the fall off in IgG and growth factor content, studies examining the biological activity of BC collected on day 1 post-calving versus day 3 have demonstrated major differences in their ability to stimulate the growth and repair of human gut cells in in vitro models of gastric damage [83] and in reducing increased gut permeability in humans [129]. However, differences in the BC collection period are not the only cause of bioactive variability; variation in storage conditions, processing, and pasteurisation may also contribute to the six-fold difference in bioactivity seen when commercial products were compared [83]. These wide variations in bioactivity are of particular concern if BC is being used as a therapeutic agent for a medical condition, where consistency of the product is vital.

\section{Use of BC in Combination with Other Nutraceuticals}

Although the focus of this article relates to use of $\mathrm{BC}$ as a single immunomodulatory/protective agent, several products are commercially available that comprise BC in combination with one or more additional components and are sold as supplements or 
foodstuffs. These additional components include proteins, egg, carbohydrates, vitamins, probiotics, and plant polyphenols. Some combinations have been examined using crossover randomised trials to establish additive or synergistic effects. Examples include reports showing synergistic effects, when $\mathrm{BC}$ and zinc carnosine were combined for reducing exercise induced raised gut permeability [130], and when BC was combined with chicken eggs in promoting the growth and repair of human gut cell lines and in reducing DSS-induced colitis in mice [131]. However, most combination products have not undergone vigorous testing to show the benefit of using more than one nutraceutical. Readers interested in the use of combination products for sports nutrition are referred to [132] and the upcoming article in this Special Issue on the "Use of BC in Sports Medicine" by Davison G.

\section{BC Use in Human and Veterinary Health}

Separate articles to be published within this Special Issue will cover the relevance of BC for use in gastrointestinal damage (see Chandwe K. and Kelly M.P.), immunology (see Ghosh S. et al.), paediatrics (see Caitlin V., Burrin D. and Sangild P.) and sports medicine (see Davidson G. et al.). These will, therefore, only be covered briefly in this article.

\subsection{BC Therapy for Human Gastrointestinal (GI) Health and Disease}

Whatever the initiating injury, denuded areas of the gut undergo repair via standard processes. Rapidly after injury, surviving cells at the wound margin migrate across the denuded region to re-form a continuous epithelial layer, a process termed restitution. Twenty-four to forty-eight hours later, there is increased proliferation to replenish lost cells. $\mathrm{BC}$ stimulated both cell migration and proliferation when tested against multiple human and rodent intestinal cell lines. A typical pro-migratory response of a gastrointestinal cell line to the presence of $B C$ is shown in Figure 4. In addition, the immune modulatory components within $\mathrm{BC}$ are probably also relevant in limiting excess inflammatory responses (as shown in Figure 2).

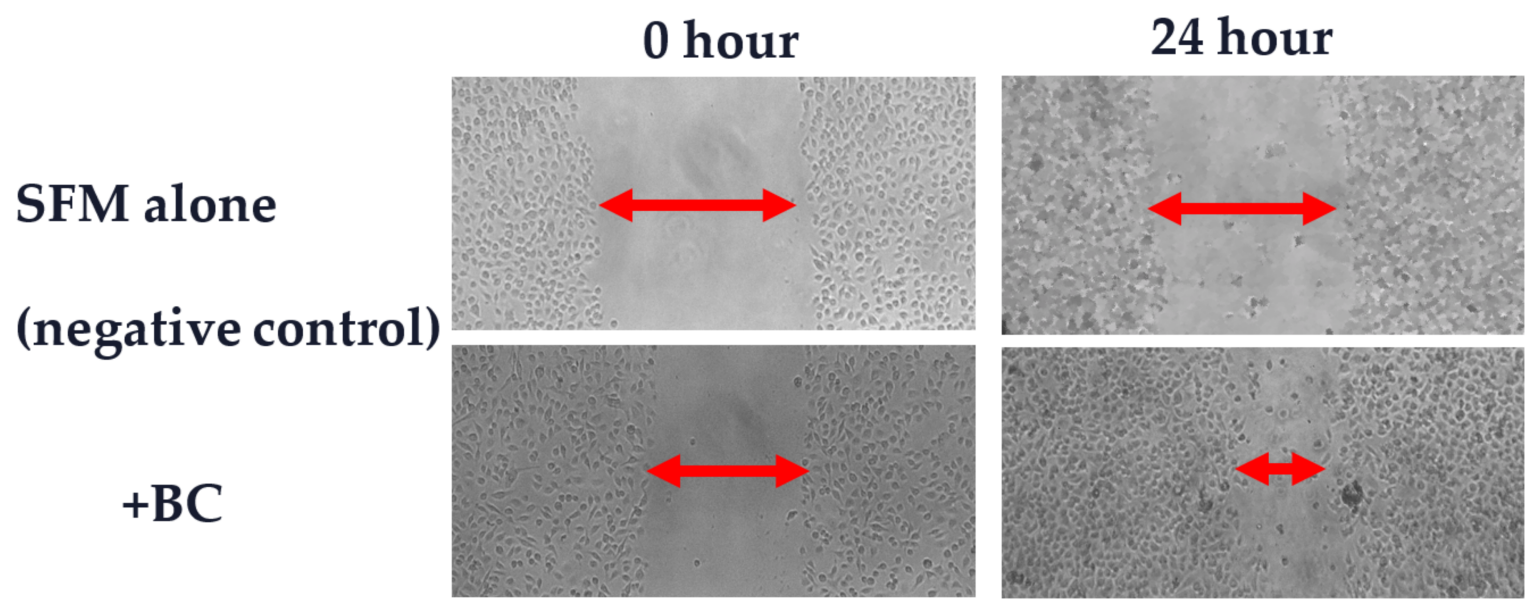

Figure 4. Effect of BC on cell migration. Human colonic Caco-2 cells were grown as a continuous monolayer and a standardised wound produced at time 0 . The amount of closure of wound was assessed $24 \mathrm{~h}$ later. The presence of BC significantly increased the rate of closure compared to cells grown in serum free medium (SFM, negative control) alone.

$\mathrm{BC}$ shows therapeutic potential for a variety of GI conditions, including nonsteroidal anti-inflammatory drug (NSAID) gut injury [2], short bowel syndrome, chemotherapy induced mucositis (particularly oral mucositis) [133], and inflammatory bowel disease [134,135]. In addition, preclinical studies using BC or its hyperimmune variants show promise for several gastrointestinal infectious diseases, such as Clostridium difficile [136]. The mechanisms of action of $\mathrm{BC}$ in these conditions will be discussed in detail in the accompanying review articles on the effect of $\mathrm{BC}$ on gastrointestinal injury, paediatrics, and immune 
function, but one potential mechanism of action, relevant for all these situations, may be through modulating the gut microbiome. It is well established that breast feeding of human infants results in a gut microbiota dominated by species of Bifidobacterium and with decreased Enterobacteria, compared to formulae-fed infants. These differences are likely to be due, at least in part, to differences in oligosaccharides and other prebiotic factors present in human and formula milk [137]. Many of the GI conditions mentioned above, such as NSAID-gut injury, necrotising enterocolitis, and inflammatory bowel disease, have been shown to have associated dysbiosis, and several animal models of GI disease have demonstrated that $\mathrm{BC}$ favourably alters gut microbiome as well as improving healing, suggesting a causal link [138]. However, the evidence from human clinical trials that the gut microbiome is significantly altered by $\mathrm{BC}$ administration, or is an important mechanism in mediating repair, is less clear, and further studies are required. For example, one study examining the effect of egg and $\mathrm{BC}$ on children with growth stunting did not find any substantial difference in the $16 \mathrm{~S}$ configuration of the faecal microbiota between children receiving BC/egg and the control group, although there was an increase in Streptococcus thermophilus, which may function as a probiotic [139]. BC is also likely to directly affect the gut mucosa, and studies on animal models and human subjects suggest the $\mathrm{BC}$ can reduce apoptosis in damaged areas through actions on Caspases, bcl-2 and HSP70, in addition to strengthening tight junctions through actions on occludin, claudin and zonulin $[130,140]$.

\section{2. $B C$ and Immune Function in Health and Disease}

The immune components of $\mathrm{BC}$ offer potential for a range of conditions. It is unlikely that the bovine IgGs are absorbed into the human systemic circulation intact, but there is mounting evidence that ingestion of $\mathrm{BC}$ can influence immune function outside of the GI tract. Examples include findings that $\mathrm{BC}$ supplementation reduced the number of flu-like episodes [141]. BC supplementation has also been reported to be beneficial in reducing the number of upper respiratory tract infections (URTIs) and diarrhoeal episodes in children [142,143], and BC IgG has been shown to bind and neutralise human respiratory syncytial virus [144]. Similarly, athletes undergoing training are known to have increased risk of URTI symptoms, and metanalyses of published trials reported a significant positive effect of BC supplementation [145]. Additional studies examining the efficacy of BC to enhance immune function in different age groups and influence sensitivity to URTI and other infections would be of value. Interested readers are referred to the companion articles currently being published on the "Effect of BC on Immune Function" (Ghosh et al) and the "Use of BC in Sports Medicine" (Davison G.).

\section{3. $B C$ and Skin}

Although there are only limited data, in vitro studies have shown that BC induces proliferation and differentiation of skin [146] and stimulates repair and reduces artificially induced inflammation in animal models $[147,148]$. Subcomponents of BC have also shown beneficial effects; for example, topical administration of lactoferrin reduced inflammation in human volunteers exposed to local skin allergens [149].

\subsection{BC and Bone Density}

Animal models suggest that $B C$ supplementation may have value in increasing bone density in juvenile rats [150]. There are limited randomised human clinical trials examining the effect of $\mathrm{BC}$ on bone density, although one study reported $\mathrm{BC}$ supplementation during resistance training increased both leg press strength and truncated bone resorption in older adults [151].

\subsection{BC, Diabetes, Hypercholesterolemia, and Non-Alcoholic Fatty Liver Disease (NAFLD)}

Several studies in animals and humans suggest that $B C$ may have value in reducing raised glucose and lipids in Type-2 diabetic subjects [152,153], patients with hypercholesterolemia, and/or suffering from NAFLD [154,155]. All these conditions may occur in the 
same patient and have similar pathophysiological processes. These include relative insulin resistance, low grade chronic inflammation in multiple tissues including fat and increased gut permeability, possibly due to the disruption of intestinal intercellular tight junctions contributed to by the presence of gut luminal bacterial lipopolysaccharides. The beneficial effects of $\mathrm{BC}$ for these conditions are likely to be due to multiple constituents that affect interaction with luminal bacteria and lipopolysaccharide (LPS), mucosal integrity, and innate and adaptive immune responses. Some of these mechanisms are shown in Figure 2B. Evidence in support of BC influencing the patients' immune responses in these conditions include findings that BC administration decreases serum tumour necrosis factor (TNF)- $\alpha$ levels, in addition to increasing the number of splenic NKT cells [156] and circulating CD4+ CD25+ HLA-DR T reg cells [155]. Readers interested in a detailed review of the immune effects of $\mathrm{BC}$ are referred to the upcoming article by Ghosh $\mathrm{S}$ et al.

\subsection{BC in Veterinary Practice}

Calf survival and postweaning morbidity and mortality are significantly reduced if the new-born calf receives BC within the first few hours after birth [126]. It is therefore important that new-born calves receive sufficient BC during this period. Large amounts of $B C$ remain available that are surplus to the calf's requirements, and this is collected and processed as described earlier. The use of BC in veterinary practice falls outside the usual scope of Nutrients, and this section, therefore, only briefly reviews some of the evidence for benefit of $\mathrm{BC}$ use in both production and companion animals. Interested readers are referred to the specialist articles cited.

\subsubsection{Use of BC in Production Animals}

For calves, early feeding of BC within the first hours of life is critical for their health and survival. General guidelines are a first feeding of approximately $10 \%$ of the calf's weight in BC. This early feeding provides the immunoglobulins the calf requires to enable passive immunity during the first $24 \mathrm{~h}$ prior to gut closure, during which time the immunoglobulins can reach the calf's circulatory system [15]. Early BC feeding increases daily weight gain during the calf's growth period and beneficial effects are maintained long-term, with the adult dams who had been fed BC as a calf producing increased milk yields. [157]. Furthermore, calves who were not given BC had a 74-fold higher likelihood of mortality by 21 days of life than those who received more than two quarts of BC within the first $6 \mathrm{~h}$ of postnatal life [158]. The beneficial effects of BC ingestion in cows are likely to be due, at least in part, to raising serum (and gut luminal) IgG, enhancing the calf's ability to fight infection. Other factors that may also be involved include altering immune responses via cytokine constituents, altering the faecal microbiome, and anabolic effects of hormones and growth factors within $\mathrm{BC}$ on the gut and in other tissues.

For piglets, the postweaning period is a critical time, where susceptibility to environmental pathogens and gut-associated pathologies can impact the production pig's size and survival. For example, the piglet small intestine loses $20-30 \%$ of its weight in the first two days post-weaning [159]. In this same study, BC administration was shown to enhance weight gain and systemic IgA response [159]. Similarly, in piglets weaned at 21 days who received $\mathrm{BC}$ for two weeks following weaning, there were beneficial effects on intestinal morphology, including increased villi height, decreased crypt depth, and increased epithelial cell height in the small intestine [160]. This beneficial effect of BC in piglets is further supported by studies showing a positive effect of BC on average daily food intake and weight gain during the first week of the postweaning period [161]. Mechanisms of action of $\mathrm{BC}$ in pigs are likely to be similar to those for use in cattle.

For poultry, feed conversion efficiency is important for broiler farms, because the reduction in feed needed during the growth and finishing periods greatly impacts costs. A trial of BC supplementation ( $5 \%$ by weight) into the feed of broiler chicks for the first two weeks after hatching showed greater feed conversion efficiency in the BC group [162]. 
Similarly, BC supplementation to young broilers (1-10 days old) under heat stress showed benefits on thigh and breast size compared to the control group [163].

\subsubsection{Use of BC in Canine and Equine Animals}

In canines, studies have suggested benefits for the use of BC for gastrointestinal health, digestion, and immune support. In puppies, a study on recently weaned toy breed puppies found that $0.5 \mathrm{~g}$ of $\mathrm{BC}$ per day for ten days improved faecal quality, as measured by the WALTHAM faecal scoring system, compared to puppies receiving milk powder as a control [164]. Additionally, in published abstract conference proceedings [165], a pilot crossover trial supplemented a group of neutered male beagles with $1 \mathrm{~g}$ of $\mathrm{BC}$ per day for three weeks, in addition to a set of four probiotic strains at $2.9 \times 10^{9}$ colony forming units. They did not observe changes in faecal microbiota, but did see improvements in protein digestibility in the BC-supplemented group. In another study, supplementation of 2-7-year-old huskies with BC for 40 weeks increased faecal IgA levels compared to controls, suggesting enhanced gut-associated lymph tissue function. In addition, they responded to canine distemper virus (CDV) vaccination with higher plasma levels of anti-CDV IgG, and had increased faecal microbiota diversity, suggesting positive effects on immune function and gut microbiome [7].

For horses, it has been shown that immunoglobulins from BC can be absorbed by new-born foals, with the bovine IgG remaining in the circulation with a half-life of seven days [166]. The beneficial effect of $\mathrm{BC}$ ingestion by horses is also supported by findings that thoroughbred yearlings who received $\mathrm{BC}$ had two-week shortening of illness due to respiratory disease when compared to control yearlings during the 22-week supplementation period [6]. Furthermore, in a randomised cross-over trial, racing thoroughbreds earned more race purse money, ran faster races, and were able to return to racing a week faster during the period they were supplemented with $\mathrm{BC}$ compared to the period when they were not [5]. To assuage concerns about potential increases in serum growth factor levels, the same group completed a trial confirming that 200 grams per day of BC powder did not increase serum IGF-1 concentrations after two and four weeks of supplementation in thoroughbred horses [167], which is consistent with human studies discussed earlier.

\section{Conclusions}

$\mathrm{BC}$ is a rich source of macro- and micro-nutrients, immune modulators (including IgGs), growth factors, and other bioactive molecules. Current farming methods enable the production of large volumes of $\mathrm{BC}$ for clinical and veterinary use. Batch variation during production must be kept to a minimum to ensure reproducible content of constituents, and bioactivity and quality control procedures need to ensure that the processing and storage methods used are optimised to maintain stability. In the general health support market, $\mathrm{BC}$ has several advantages over single ingredient supplements; it is perceived as being a comprehensive "superfood", with customer appreciation of its links to natures first food from breastfeeding. BC has a strong safety profile, relevance across all age groups, and is delivered in a natural formulation that limits its own inactivation when taken orally. These aspects should facilitate greater consumer and patient acceptance and compliance to achieve optimal immune and digestive health. In addition to administering BC on its own, additional therapeutic value may be gained if the $\mathrm{BC}$ is specifically tailored for individual conditions, e.g., administering hyperimmune milk or BC to immunocompromised patients who have gut disease, thereby addressing the problem of the gut infection while also enhancing gut repair. BC efficacy may also be increased if administered in combination with other factors that act synergistically with BC.

Author Contributions: Conceptualization, R.J.P.; writing-original draft preparation, R.J.P. and M.J.W.; writing-review and editing, R.J.P. and M.J.W. All authors have read and agreed to the published version of the manuscript. 
Funding: Funding for this article was provided by PanTheryx Inc. R.J.P. and M.J.W. are employees of Pantheryx Inc. PanTheryx did not have any additional role in the decision to publish, or preparation of the manuscript.

Institutional Review Board Statement: Data shown in Figure 2A was kindly provided by Drs P Lalor and L Sheriff, University of Birmingham. Collection and analyses of blood samples was conducted according to the guidelines of the Declaration of Helsinki and approved by relevant Ethics Committee of University of Birmingham, UK (active 2019-20).

Informed Consent Statement: Informed consent was obtained from all subjects providing blood samples shown in Figure 2A.

Data Availability Statement: Articles are licensed under an open access Creative Commons CC BY 4.0 license, meaning that anyone may download and read the paper for free.

Conflicts of Interest: PanTheryx Inc supply BC to U.S., European, and Asia-Pacific markets. This does not affect our adherence to the Nutrients policies regarding sharing data and materials.

\begin{abstract}
Abbreviations
DSS, dextran sodium sulphate; EGF; epidermal growth factor; EGFR, epidermal growth factor receptor; Ig, immunoglobulin; IGF, insulin-like growth factor; MDGF, milk-derived growth factor; MFG-E8, Milk fat globule epidermal growth factor 8; NSAID, nonsteroidal anti-inflammatory drugs; PDGF, platelet-derived growth factor; SFM, serum-free medium; TGF- $\alpha$, transforming growth factor $\alpha$; TGF- $\beta$, transforming growth factor $\beta$; VEGF, vascular endothelial growth factor.
\end{abstract}

\title{
References
}

1. Panahi, Y.; Falahi, G.; Falahpour, M.; Moharamzad, Y.; Khorasgani, M.R.; Beiraghdar, F.; Naghizadeh, M.M. Bovine colostrum in the management of nonorganic failure to thrive: A randomized clinical trial. J. Pediatr. Gastroenterol. Nutr. 2010, 50, 551-554. [CrossRef]

2. Playford, R.J.; Macdonald, C.E.; Calnan, D.P.; Floyd, D.N.; Podas, T.; Johnson, W.; Wicks, A.C.; Bashir, O.; Marchbank, T. Coadministration of the health food supplement, bovine colostrum, reduces the acute non-steroidal anti-inflammatory drug-induced increase in intestinal permeability. Clin. Sci. 2001, 100, 627-633. [CrossRef]

3. Buckley, J.D.; Brinkworth, G.D.; Abbott, M.J. Effect of bovine colostrum on anaerobic exercise performance and plasma insulin-like growth factor I. J. Sports Sci. 2003, 21, 577-588. [CrossRef]

4. Kotsis, Y.; Mikellidi, A.; Aresti, C.; Persia, E.; Sotiropoulos, A.; Panagiotakos, D.B.; Antonopoulou, S.; Nomikos, T. A lowdose, 6-week bovine colostrum supplementation maintains performance and attenuates inflammatory indices following a Loughborough Intermittent Shuttle Test in soccer players. Eur. J. Nutr. 2018, 57, 1181-1195. [CrossRef]

5. $\quad$ Fenger, C.K.; Tobin, T.; Casey, P.J.; Roualdes, E.A.; Langemeier, J.L.; Haines, D.M. Bovine colostrum supplementation optimises earnings, performance and recovery in racing thoroughbreds. Comp. Exerc. Physiol. 2014, 10, 233-238. [CrossRef]

6. Fenger, C.K.; Tobin, T.; Casey, P.J.; Roualdes, E.A.; Langemeier, J.L.; Cowles, R.; Haines, D.M. Enhanced Bovine Colostrum Supplementation Shortens the Duration of Respiratory Disease in Thoroughbred Yearlings. J. Equine Vet. Sci. 2016, 42, 77-81. [CrossRef]

7. Satyaraj, E.; Reynolds, A.; Pelker, R.; Labuda, J.; Zhang, P.; Sun, P. Supplementation of diets with bovine colostrum influences immune function in dogs. Br. J. Nutr. 2013, 110, 2216-2221. [CrossRef]

8. Hadorn, U.; Hammon, H.; Bruckmaier, R.M.; Blum, J.W. Delaying Colostrum Intake by One Day Has Important Effects on Metabolic Traits and on Gastrointestinal and Metabolic Hormones in Neonatal Calves. J. Nutr. 1997, 127, 2011-2023. [CrossRef] [PubMed]

9. Yvon, M.; Levieux, D.; Valluy, M.C.; Pelissier, J.P.; Mirand, P.P. Colostrum protein digestion in newborn lambs. J. Nutr. 1993, 123, 586-596. [CrossRef]

10. Ginger, M.R.; Grigor, M.R. Comparative aspects of milk caseins. Comp. Biochem. Physiol. B Biochem. Mol. Biol. 1999, 124, 133-145. [CrossRef]

11. Daniel, H.; Vohwinkel, M.; Rehner, G. Effect of casein and $\beta$-casomorphins on gastrointestinal motility in rats. J. Nutr. 1990, 120, 252-257. [CrossRef]

12. Pessi, T.; Isolauri, E.; Sütas, Y.; Kankaanranta, H.; Moilanen, E.; Hurme, M. Suppression of T-cell activation by Lactobacillus rhamnosus GG-degraded bovine casein. Int. Immunopharmacol. 2001, 1, 211-218. [CrossRef]

13. Meister, D.; Bode, J.; Shand, A.; Ghosh, S. Anti-inflammatory effects of enteral diet components on Crohn's disease-affected tissues in vitro. Digest. Liver Dis. 2002, 34, 430-438. [CrossRef]

14. Playford, R.J.; Woodman, A.C.; Vesey, D.; Deprez, P.H.; Calam, J.; Watanapa, P.; Williamson, R.C.N.; Clark, P. Effect of luminal growth factor preservation on intestinal growth. Lancet 1993, 341, 843-848. [CrossRef] 
15. Godden, S.M.; Lombard, J.E.; Woolums, A.R. Colostrum Management for Dairy Calves. Vet. Clin. N. Am. Food Anim. Pract. 2019, 35, 535-556. [CrossRef] [PubMed]

16. Kimura, T.; Murakawa, Y.; Ohno, M.; Ohtani, S.; Higaki, K. Gastrointestinal absorption of recombinant human insulin-like growth factor-I in rats. J. Pharmacol. Exp. Ther. 1997, 283, 611-618. [PubMed]

17. Kanwar, J.; Kanwar, R.; Sun, X.; Punj, V.; Matta, H.; Morley, S.; Parratt, A.; Puri, M.; Sehgal, R. Molecular and Biotechnological Advances in Milk Proteins in Relation to Human Health. Curr. Protein Peptide Sci. 2009, 10, 308-338. [CrossRef] [PubMed]

18. Bastian, S.E.P.; Dunbar, A.J.; Priebe, I.K.; Owens, P.C.; Goddard, C. Measurement of betacellulin levels in bovine serum, colostrum and milk. J. Endocrinol. 2001, 168, 203-212. [CrossRef] [PubMed]

19. Kuiken, K.A.; Pearson, P.B. The essential amino acid (except tryptophan) content of colostrum and milk of the cow and ewe. J. Nutr. 1949, 39, 167-176. [CrossRef]

20. Matsumoto, H.; Shimokawa, Y.; Ushida, Y.; Toida, T.; Hayasawa, H. New Biological Function of Bovine $\alpha$-Lactalbumin: Protective Effect against Ethanol- and Stress-induced Gastric Mucosal Injury in Rats. Biosci. Biotechnol. Biochem. 2001, 65, $1104-1111$. [CrossRef]

21. Nciuc, N.S.T. $\breve{A}$; Râpeanu, G. An overview of bovine $\alpha$-lactalbumin stucture and functionality. Ann. Univ. Dunarea Jos Galati Fascicle VI Food Technol. 2010, 34, 82-93.

22. Kiewiet, M.B.G.; Dekkers, R.; Gros, M.; van Neerven, R.J.J.; Groeneveld, A.; de Vos, P.; Faas, M.M. Toll-like receptor mediated activation is possibly involved in immunoregulating properties of cow's milk hydrolysates. PLoS ONE 2017, 12, e0178191. [CrossRef]

23. Kehoe, S.I.; Jayarao, B.M.; Heinrichs, A.J. A survey of bovine colostrum composition and colostrum management practices on Pennsylvania dairy farms. J. Dairy Sci. 2007, 90, 4108-4116. [CrossRef]

24. Urashima, T.; Saito, T.; Nakamura, T.; Messer, M. Oligosaccharides of milk and colostrum in non-human mammals. Glycoconj. J. 2001, 18, 357-371. [CrossRef]

25. Coelho, A.I.; Berry, G.T.; Rubio-Gozalbo, M.E. Galactose metabolism and health. Curr. Opin. Clin. Nutr. Metab. Care 2015, 18, 422-427. [CrossRef]

26. Ten Bruggencate, S.J.; Bovee-Oudenhoven, I.M.; Feitsma, A.L.; van Hoffen, E.; Schoterman, M.H. Functional role and mechanisms of sialyllactose and other sialylated milk oligosaccharides. Nutr. Rev. 2014, 72, 377-389. [CrossRef]

27. Zivkovic, A.M.; Barile, D. Bovine milk as a source of functional oligosaccharides for improving human health. Adv. Nutr. 2011, 2, 284-289. [CrossRef]

28. Gopal, P.K.; Gill, H.S. Oligosaccharides and glycoconjugates in bovine milk and colostrum. Br. J. Nutr. 2000, 84, 69-74. [CrossRef]

29. Martín-Sosa, S.; Martín, M.J.; García-Pardo, L.A.; Hueso, P. Sialyloligosaccharides in human and bovine milk and in infant formulas: Variations with the progression of lactation. J. Dairy Sci. 2003, 86, 52-59. [CrossRef]

30. Underwood, M.A.; German, J.B.; Lebrilla, C.B.; Mills, D.A. Bifidobacterium longum subspecies infantis: Champion colonizer of the infant gut. Pediatr. Res. 2015, 77, 229-235. [CrossRef]

31. Bondue, P.; Crèvecoeur, S.; Brose, F.; Daube, G.; Seghaye, M.C.; Griffiths, M.W.; LaPointe, G.; Delcenserie, V. Cell-free spent media obtained from Bifidobacterium bifidum and Bifidobacterium crudilactis grown in media supplemented with $3^{\prime}$-sialyllactose modulate virulence gene expression in Escherichia coli O157: H7 and Salmonella Typhimurium. Front. Microbiol. 2016, 7, 1460. [CrossRef]

32. O'Riordan, N.; O'Callaghan, J.; Buttò, L.F.; Kilcoyne, M.; Joshi, L.; Hickey, R.M. Bovine glycomacropeptide promotes the growth of Bifidobacterium longum ssp. infantis and modulates its gene expression. J. Dairy Sci. 2018, 101, 6730-6741. [CrossRef]

33. Contarini, G.; Povolo, M.; Pelizzola, V.; Monti, L.; Bruni, A.; Passolungo, L.; Abeni, F.; Degano, L. Bovine colostrum: Changes in lipid constituents in the first 5 days after parturition. J. Dairy Sci. 2014, 97, 5065-5072. [CrossRef]

34. O'Callaghan, T.F.; O’Donovan, M.; Murphy, J.P.; Sugrue, K.; Mannion, D.; McCarthy, W.P.; Timlin, M.; Kilcawley, K.N.; Hickey, R.M.; Tobin, J.T. Evolution of the bovine milk fatty acid profile-From colostrum to milk five days post parturition. Int. Dairy J. 2020, 104, 8721-8731. [CrossRef]

35. Verardo, V.; Gómez-Caravaca, A.M.; Arráez-Román, D.; Hettinga, K. Recent advances in phospholipids from colostrum, milk and dairy by-products. Int. J. Mol. Sci. 2017, 18, 173. [CrossRef]

36. Miles, E.A.; Calder, P.C. The influence of the position of palmitate in infant formula triacylglycerols on health outcomes. Nutr. Res. 2017, 44, 1-8. [CrossRef]

37. Bar-Yoseph, F.; Lifshitz, Y.; Cohen, T. Review of sn-2 palmitate oil implications for infant health. Prostaglandins Leukot. Essent. Fatty Acids 2013, 89, 139-143. [CrossRef]

38. Sales-Campos, H.; Reis de Souza, P.; Crema Peghini, B.; Santana da Silva, J.; Ribeiro Cardoso, C. An Overview of the Modulatory Effects of Oleic Acid in Health and Disease. Mini Rev. Med. Chem. 2013, 13, 201-210.

39. Cleminson, J.S.; Zalewski, S.P.; Embleton, N.D. Nutrition in the preterm infant: What's new? Curr. Opin. Clin. Nutr. Metab. Care 2016, 19, 220-225.

40. Pereira, P.C. Milk nutritional composition and its role in human health. Nutrition 2014, 30, 619-627. [CrossRef]

41. Bagwe, S.; Tharappel, L.J.P.; Kaur, G.; Buttar, H.S. Bovine colostrum: An emerging nutraceutical. J. Complement. Integr. Med. 2015, 12, 175-185. [CrossRef] 
42. Bagwe-Parab, S.; Yadav, P.; Kaur, G.; Tuli, H.S.; Buttar, H.S. Therapeutic Applications of Human and Bovine Colostrum in the Treatment of Gastrointestinal Diseases and Distinctive Cancer Types: The Current Evidence. Front. Pharmacol. 2020, 11, 1100. [CrossRef]

43. Pakkanen, R.; Aalto, J. Growth factors and antimicrobial factors of bovine colostrum. Int. Dairy J. 1997, 7, 285-297. [CrossRef]

44. Kelly, G.S. Bovine colostrum: A review of clinical uses. Altern. Med. Rev. 2003, 8, 378-394.

45. Stelwagen, K.; Carpenter, E.; Haigh, B.; Hodgkinson, A.; Wheeler, T.T. Immune components of bovine colostrum and milk. J. Anim. Sci. 2009, 87, 3-9. [CrossRef]

46. Ulfman, L.H.; Leusen, J.H.W.; Savelkoul, H.F.J.; Warner, J.O.; van Neerven, R.J.J. Effects of Bovine Immunoglobulins on Immune Function, Allergy, and Infection. Front. Nutr. 2018, 5, 1-20. [CrossRef]

47. Tacket, C.O.; Losonsky, G.; Link, H.; Hoang, Y.; Guesry, P.; Hilpert, H.; Levine, M.M. Protection by Milk Immunoglobulin Concentrate against Oral Challenge with Enterotoxigenic Escherichia coli. N. Engl. J. Med. 1988, 318, 1240-1243. [CrossRef]

48. Ebina, T.; Ohta, M.; Kanamaru, Y.; Yamamoto-Osumi, Y.; Baba, K. Passive immunizations of suckling mice and infants with bovine colostrum containing antibodies to human rotavirus. J. Med. Virol. 1992, 38, 117-123. [CrossRef]

49. Hodgkinson, A.J.; Cannon, R.D.; Holmes, A.R.; Fischer, F.J.; Willix-Payne, D.J. Production from dairy cows of semi-industrial quantities of milk-protein concentrate (MPC) containing efficacious anti-Candida albicans IgA antibodies. J. Dairy Res. 2007, 74, 269-275. [CrossRef]

50. Loimaranta, V.; Laine, M.; Söderling, E.; Vasara, E.; Rokka, S.; Marnila, P.; Korhonen, H.; Tossavainen, O.; Tenovuo, J. Effects of bovine immune and non-immune whey preparations on the composition and $\mathrm{pH}$ response of human dental plaque. Eur. J. Oral Sci. 1999, 107, 244-250. [CrossRef]

51. Wilson, D.; Evans, M.; Weaver, E.; Shaw, A.L.; Klein, G.L. Evaluation of serum-derived bovine immunoglobulin protein isolate in subjects with diarrhea-predominant irritable bowel syndrome. Clin. Med. Insights Gastroenterol. 2013, 6, 49-60. [CrossRef] [PubMed]

52. Morrin, S.T.; Lane, J.A.; Marotta, M.; Bode, L.; Carrington, S.D.; Irwin, J.A.; Hickey, R.M. Bovine colostrum-driven modulation of intestinal epithelial cells for increased commensal colonisation. Appl. Microbiol. Biotechnol. 2019, 103, 2745-2758. [CrossRef] [PubMed]

53. Douëllou, T.; Montel, M.C.; Thevenot Sergentet, D. Invited review: Anti-adhesive properties of bovine oligosaccharides and bovine milk fat globule membrane-associated glycoconjugates against bacterial food enteropathogens. J. Dairy Sci. 2017, 100, 3348-3359. [CrossRef] [PubMed]

54. Seifu, E.; Buys, E.M.; Donkin, E.F. Significance of the lactoperoxidase system in the dairy industry and its potential applications: A review. Trends Food Sci. Technol. 2005, 16, 137-145. [CrossRef]

55. Wheeler, T.T.; Hodgkinson, A.J.; Prosser, C.G.; Davis, S.R. Immune components of colostrum and milk-A historical perspective. J. Mammary Gland Biol. Neoplasia 2007, 12, 237-247. [CrossRef]

56. Clare, D.; Catignani, G.; Swaisgood, H. Biodefense Properties of Milk: The Role of Antimicrobial Proteins and Peptides. Curr. Pharm. Des. 2005, 9, 1239-1255. [CrossRef]

57. Lönnerdal, B. Nutritional and physiologic significance of human milk proteins. Am. J. Clin. Nutr. 2003, 77, 1537S-1543S. [CrossRef]

58. Masson, P.L.; Heremans, J.F. Lactoferrin in milk from different species. Comparat. Biochem. Physiol. Part B Biochem. Physiol. 1971, 39, IN11-IN13. [CrossRef]

59. Sanchez, L.; Aranda, P.; Perez, M.; Calvo, M. Concentration of Lactoferrin and Transferrin throughout Lactation in Cow's Colostrum and Milk. Biol. Chem. Hoppe-Seyler 1988, 369, 1005-1008. [CrossRef]

60. Arnold, R.R.; Brewer, M.; Gauthier, J.J. Bactericidal activity of human lactoferrin: Sensitivity of a variety of microorganisms. Infect. Immun. 1980, 28, 893-898.

61. Aisen, P.; Listowsky, I. Iron transport and storage proteins. Ann. Rev. Biochem. 1980, 49, 357-393. [CrossRef] [PubMed]

62. Zhao, X.; Xu, X.-X.; Liu, Y.; Xi, E.-Z.; An, J.-J.; Tabys, D.; Liu, N. The In Vitro Protective Role of Bovine Lactoferrin on Intestinal Epithelial Barrier. Molecules 2019, 24, 148. [CrossRef] [PubMed]

63. King, J.C.; Cummings, G.E.; Guo, N.; Trivedi, L.; Readmond, B.X.; Keane, V.; Feigelman, S.; de Waard, R. A double-blind, placebo-controlled, pilot study of bovine lactoferrin supplementation in bottle-fed infants. J. Pediatr. Gastroenterol. Nutr. 2007, 44, 245-251. [CrossRef] [PubMed]

64. Ochoa, T.J.; Chea-Woo, E.; Campos, M.; Pecho, I.; Prada, A.; McMahon, R.J.; Cleary, T.G. Impact of lactoferrin supplementation on growth and prevalence of Giardia colonization in children. Clin. Infect. Dis. 2008, 46, 1881-1883. [CrossRef]

65. Kruzel, M.L.; Bacsi, A.; Choudhury, B.; Sur, S.; Boldogh, I. Lactoferrin decreases pollen antigen-induced allergic airway inflammation in a murine model of asthma. Immunology 2006, 119, 159-166. [CrossRef]

66. Pammi, M.; Suresh, G. Enteral lactoferrin supplementation for prevention of sepsis and necrotizing enterocolitis in preterm infants. Cochrane Database Syst. Rev. 2017, 3, CD007137. [CrossRef]

67. Tacket, C.O.; Binion, S.B.; Bostwick, E.; Losonsky, G.; Roy, M.J.; Edelman, R. Efficacy of bovine milk immunoglobulin concentrate in preventing illness after Shigella flexneri challenge. Am. J. Trop. Med. Hyg. 1992, 47, 276-283. [CrossRef]

68. Jones, A.W.; March, D.S.; Thatcher, R.; Diment, B.; Walsh, N.P.; Davison, G. The effects of bovine colostrum supplementation on in vivo immunity following prolonged exercise: A randomised controlled trial. Eur. J. Nutr. 2019, 58, 335-344. [CrossRef] 
69. He, F.; Tuomola, E.; Arvilommi, H.; Salminen, S. Modulation of human humoral immune response through orally administered bovine colostrum. FEMS Immunol. Med. Microbiol. 2001, 31, 93-96. [CrossRef]

70. Dinarello, C.A. The interleukin-1 family: 10 years of discovery. FASEB J. 1994, 8, 1314-1325. [CrossRef]

71. Rathe, M.; Müller, K.; Sangild, P.T.; Husby, S. Clinical applications of bovine colostrum therapy: A systematic review. Nutr. Rev. 2014, 72, 237-254. [CrossRef] [PubMed]

72. Saraiva, M.; Vieira, P.; O'Garra, A. Biology and therapeutic potential of interleukin-10. J. Exp. Med. 2020, 217, e20190418. [CrossRef] [PubMed]

73. An, M.J.; Cheon, J.H.; Kim, S.W.; Park, J.J.; Moon, C.M.; Han, S.Y.; Kim, E.S.; Kim, T.I.; Kim, W.H. Bovine colostrum inhibits nuclear factor kB-mediated proinflammatory cytokine expression in intestinal epithelial cells. Nutr. Res. 2009, 29, 275-280. [CrossRef] [PubMed]

74. Wilson, A.J.; Byron, K.; Gibson, P.R. Interleukin-8 stimulates the migration of human colonic epithelial cells in vitro. Clin. Sci. 1999, 97, 385-390. [CrossRef]

75. Barrington, G.M.; Besser, T.E.; Davis, W.C.; Gay, C.C.; Reeves, J.J.; McFadden, T.B. Expression of Immunoglobulin G1 Receptors by Bovine Mammary Epithelial Cells and Mammary Leukocytes. J. Dairy Sci. 1997, 80, 86-93. [CrossRef]

76. Van Hese, K.; Goossens, L.; Vandaele, G. Opsomer, Invited review: MicroRNAs in bovine colostrum-Focus on their origin and potential health benefits for the calf. J. Dairy Sci. 2020, 103, 1-15. [CrossRef]

77. Beshay, E.; Prud'homme, G.J. Towards an understanding of biological role of colostrinin peptides. J. Mol. Neurosci. 2001, 17, 379-389.

78. Rattray, M. Technology evaluation: Colostrinin, ReGen. Curr. Opin. Mol. Ther. 2005, 7, 78-84.

79. Zabłocka, A.; Sokołowska, A.; Macała, J.; Bartoszewska, M.; Mitkiewicz, M.; Janusz, M.; Wilusz, T.; Polanowski, A. Colostral Proline-Rich Polypeptide Complexes. Comparative Study of the Antioxidant Properties, Cytokine-Inducing Activity, and Nitric Oxide Release of Preparations Produced by a Laboratory and a Large-Scale Method. Int. J. Peptide Res. Ther. 2020, 26, 685-694. [CrossRef]

80. Boldogh, I.; Aguilera-Aguirre, L.; Bacsi, A.; Choudhury, B.K.; Saavedra-Molina, A.; Kruzel, M. Colostrinin decreases hypersensitivity and allergic responses to common allergens. Int. Arch. Allergy Immunol. 2008, 146, 289-306. [CrossRef]

81. Ragab, S.S.; Ibrahim, M.K. Role of Bovine Colostrum and its Biofunctional Fraction PRP in Oral Treatment of Enterogenic Endotoxaemia in Rats. Int. J. Agric. Biol. 2004, 6, 576-580.

82. Hagiwara, T.; Shinoda, I.; Fukuwatari, Y.; Shimamura, S. Effects of lactoferrin and its peptides on proliferation of rat intestinal epithelial cell line, IEC-18, in the presence of epidermal growth factor. Biosci. Biotechnol. Biochem. 1995, 59, 1875-1881. [CrossRef] [PubMed]

83. Playford, R.J.; Cattell, M.; Marchbank, T. Marked variability in bioactivity between commercially available bovine colostrum for human use; implications for clinical trials. PLoS ONE 2020, 15, e0240392.

84. Daughaday, W.H.; Rotwein, P.; Rotwein, P. Insulin-like growth factors I and II. Peptide, messenger ribonucleic acid and gene structures, serum, and tissue concentrations. Endocr. Rev. 1989, 10, 68-91. [CrossRef] [PubMed]

85. Lund, P.K.; Zimmermann, E.M. Insulin-like growth factors and inflammatory bowel disease. Bailliere's Clin. Gastroenterol. 1996, 10, 83-96. [CrossRef]

86. Baxter, R.C.; Zaltsman, Z.; Turtle, J.R. Immunoreactive somatomedin-c/insulin-like growth factor I and its binding protein in human milk. J. Clin. Endocrinol. Metab. 1984, 58, 955-959. [CrossRef]

87. Vacher, P.Y.; Blum, J.W. Age dependency of insulin like growth factor 1, insulin protein and immunoglobulin concentrations and gamma glutamyl transferase activity in first colostrum of dairy cows. Milchwissenschaft 1993, 48, 423-425.

88. Collier, R.J.; Miller, M.A.; Hildebrandt, J.R.; Torkelson, A.R.; White, T.C.; Madsen, K.S.; Vicini, J.L.; Eppard, P.J.; Lanza, G.M. Factors Affecting Insulin-Like Growth Factor-I Concentration in Bovine Milk. J. Dairy Sci. 1991, 74, 2905-2911. [CrossRef]

89. Lowe, W.L. Biological actions of the insulin-like growth factors. In Insulin-like Growth Factors, Molecular and Cellular Aspects; LeRoith, D., Ed.; CRC Press: Boca Raton, FL, USA, 1991; pp. 49-85.

90. Lo, H.C.; Hinton, P.S.; Yang, H.; Unterman, T.G.; Ney, D.M. Insulin-like growth factor-I but not growth hormone attenuates dexamethasone-induced catabolism in parenterally fed rats. J. Parenter. Enter. Nutr. 1996, 20, 171-177. [CrossRef]

91. Schams, D.; Einspanier, R. Growth hormone, IGF-I and insulin in mammary gland secretion before and after parturition and possibility of their transfer into the calf. Endocr. Regul. 1991, 25, 139-143.

92. Yan, J.; Charles, J.F. Gut Microbiota and IGF-1. Calcif. Tissue Int. 2018, 102, 406-414. [CrossRef] [PubMed]

93. Heidegger, I.; Ofer, P.; Doppler, W.; Rotter, V.; Klocker, H.; Massoner, P. Diverse functions of IGF/insulin signaling in malignant and noncancerous prostate cells: Proliferation in cancer cells and differentiation in noncancerous cells. Endocrinology 2012, 153, 4633-4643. [CrossRef] [PubMed]

94. Davison, G.; Jones, A.W.; Marchbank, T.; Playford, R.J. Oral bovine colostrum supplementation does not increase circulating insulin-like growth factor-1 concentration in healthy adults: Results from short- and long-term administration studies. Eur. J. Nutr. 2019, 59, 1473-1479. [CrossRef] [PubMed]

95. Frey, M.R.; Brent Polk, D. ErbB receptors and their growth factor ligands in pediatric intestinal inflammation. Pediatr. Res. 2014, 75, 127-132. [CrossRef] [PubMed]

96. Koldovsky, O.; Britton, J.; Davis, D.; Davis, T.; Grimes, J.; Kong, W.; Rao, R.; Schaudies, P. The developing gastrointestinal tract and milk-borne epidermal growth factor. Adv. Exp. Med. Biol. 1991, 310, 99-105. [PubMed] 
97. Playford, R.J.; Marchbank, T.; Calnan, D.P.; Calam, J.; Royston, P.; Batten, J.J.; Hansen, H.F. Epidermal growth factor is digested to smaller, less active forms in acidic gastric juice. Gastroenterology 1995, 108, 92-101. [CrossRef]

98. Playford, R.J.; Hanby, A.M.; Gschmeissner, S.; Peiffer, L.P.; Wright, N.A.; McGarrity, T. The epidermal growth factor receptor (EGF-R) is present on the basolateral, but not the apical, surface of enterocytes in the human gastrointestinal tract. Gut 1996, 39, 262-266. [CrossRef]

99. Playford, R.J. Peptides and gastrointestinal mucosal integrity. Gut 1995, 37, 595-597. [CrossRef]

100. Thompson, J.F.; van den Berg, M.; Stokkers, P.C.F. Developmental regulation of epidermal growth factor receptor kinase in rat intestine. Gastroenterology 1994, 107, 1278-1287. [CrossRef]

101. Okuyama, H.; Urao, M.; Lee, D.; Drongowski, R.A.; Coran, A.G. The effect of epidermal growth factor on bacterial translocation in newborn rabbits. Proc. J. Pediatr. Surg. 1998, 33, 225-228. [CrossRef]

102. Yu, M.; Kim, J.; Ahn, J.H.; Moon, Y. Nononcogenic restoration of the intestinal barrier by E. coli-delivered human EGF. JCI Insight 2019, 4, e125166. [CrossRef] [PubMed]

103. Okada, M.; Ohmura, E.; Kamiya, Y.; Murakami, H.; Onoda, N.; Iwashita, M.; Wakai, K.; Tsushima, T.; Shizume, K. Transforming growth factor (TGF)— $\alpha$ in human milk. Life Sci. 1991, 48, 1151-1156. [CrossRef]

104. Cartlidge, S.A.; Elder, J.B. Transforming growth factor $\alpha$ and epidermal growth factor levels in normal human gastrointestinal mucosa. Br. J. Cancer 1989, 60, 657-660. [CrossRef] [PubMed]

105. Barnard, J.A.; Daniel Beauchamp, R.; Russell, W.E.; Dubois, R.N.; Coffey, R.J. Epidermal growth factor-related peptides and their relevance to gastrointestinal pathophysiology. Gastroenterology 1995, 108, 564-580. [CrossRef]

106. Dignass, A.U.; Podolsky, D.K. Cytokine modulation of intestinal epithelial cell restitution: Central role of transforming growth factor $\beta$. Gastroenterology 1993, 105, 1323-1332. [CrossRef]

107. Playford, R.J.; Floyd, D.N.; Macdonald, C.E.; Calnan, D.P.; Adenekan, R.O.; Johnson, W.; Goodlad, R.A.; Marchbank, T. Bovine colostrum is a health food supplement which prevents NSAID induced gut damage. Gut 1999, 44, 653-658. [CrossRef]

108. Walker, A. Breast Milk as the Gold Standard for Protective Nutrients. J. Pediatr. 2010, 156, S3-S7. [CrossRef]

109. McEntee, C.P.; Gunaltay, S.; Travis, M.A. Regulation of barrier immunity and homeostasis by integrin-mediated transforming growth factor $\beta$ activation. Immunology 2020, 160, 139-148. [CrossRef]

110. Shing, Y.; Davidson, S.; Klagsbrun, M. Purification of Polypeptide Growth Factors from Milk. Methods Enzymol. 1987, 146, 42-48.

111. Shing, Y.W.; Klagsbrun, M. Human and bovine milk contain different sets of growth factors. Endocrinology 1984, 115, $273-282$. [CrossRef]

112. Shing, Y.; Klagsbrun, M. Purification and characterization of a bovine colostrum-derived growth factor. Mol. Endocrinol. 1987, 1, 335-338. [CrossRef] [PubMed]

113. Keck, P.J.; Hauser, S.D.; Krivi, G.; Sanzo, K.; Warren, T.; Feder, J.; Connolly, D.T. Vascular permeability factor, an endothelial cell mitogen related to PDGF. Science 1989, 246, 1309-1312. [CrossRef] [PubMed]

114. Siafakas, C.G.; Anatolitou, F.; Fusunyan, R.D.; Walker, W.A.; Sanderson, I.R. Vascular endothelial growth factor (VEGF) is present in human breast milk and its receptor is present on intestinal epithelial cells. Pediatr. Res. 1999, 45, 652-657. [CrossRef] [PubMed]

115. Chatterton, D.E.W.; Nguyen, D.N.; Bering, S.B.; Sangild, P.T. Anti-inflammatory mechanisms of bioactive milk proteins in the intestine of newborns. Int. J. Biochem. Cell Biol. 2013, 45, 1730-1747. [CrossRef] [PubMed]

116. Yi, Y.S. Functional role of milk fat globule-epidermal growth factor VIII in macrophage-mediated inflammatory responses and inflammatory/autoimmune diseases. Mediat. Inflamm. 2016, 2016, 5628486. [CrossRef]

117. Baram, T.; Koch, Y.; Hazum, E.; Fridkin, M. Gonadotropin-releasing hormone in milk. Science 1977, 198, 300-302. [CrossRef]

118. Amit, T.; Dibner, C.; Barkey, R.J. Characterization of prolactin- and growth hormone-binding proteins in milk and their diversity among species. Mol. Cell. Endocrinol. 1997, 130, 167-180. [CrossRef]

119. Grosvenor, C.E.; Picciano, M.F.; Baumrucker, C.R. Hormones and growth factors in milk. Endocr. Rev. 1993, 14, 710-728. [CrossRef]

120. Ulshen, M.H.; Dowling, R.H.; Fuller, C.R.; Zimmermann, E.M.; Lund, P.K. Enhanced growth of small bowel in transgenic mice overexpressing bovine growth hormone. Gastroenterology 1993, 104, 973-980. [CrossRef]

121. Delehaye-Zervas, M.C.; Mertani, H.; Martini, J.F.; Nihoul-Feketé, C.; Morel, G.; Postel-Vinay, M.C. Expression of the growth hormone receptor gene in human digestive tissues. J. Clin. Endocrinol. Metab. 1994, 78, 1473-1480.

122. Jensen, E.A.; Young, J.A.; Mathes, S.C.; List, E.O.; Carroll, R.K.; Kuhn, J.; Onusko, M.; Kopchick, J.J.; Murphy, E.R.; Berryman, D.E. Crosstalk between the growth hormone/insulin-like growth factor-1 axis and the gut microbiome: A new frontier for microbial endocrinology. Growth Horm. IGF Res. 2020, 53-54, 101333. [CrossRef] [PubMed]

123. Pinotti, L.; Rosi, F. Leptin in bovine colostrum and milk. Horm. Metab. Res. 2006, 38, 89-93. [CrossRef]

124. Hedbacker, K.; Birsoy, K.; Wysocki, R.W.; Asilmaz, E.; Ahima, R.S.; Farooqi, I.S.; Friedman, J.M. Antidiabetic Effects of IGFBP2, a Leptin-Regulated Gene. Cell Metab. 2010, 11, 11-22. [CrossRef] [PubMed]

125. Chatterton, D.E.W.; Aagaard, S.; Hesselballe Hansen, T.; Nguyen, D.N.; de Gobba, C.; Lametsch, R.; Sangild, P.T. Bioactive proteins in bovine colostrum and effects of heating, drying and irradiation. Food Funct. 2020, 11, 2309-2327. [CrossRef] [PubMed]

126. McGuirk, S.M.; Collins, M. Managing the production, storage, and delivery of colostrum. Vet. Clin. N. Am. Food Anim. Pract. 2004, 20, 593-603. [CrossRef]

127. Morrill, K.M.; Conrad, E.; Lago, A.; Campbell, J.; Quigley, J.; Tyler, H. Nationwide evaluation of quality and composition of colostrum on dairy farms in the United States. J. Dairy Sci. 2012, 95, 3997-4005. [CrossRef] 
128. McGrath, B.A.; Fox, P.F.; McSweeney, P.L.H.; Kelly, A.L. Composition and properties of bovine colostrum: A review. Dairy Sci. Technol. 2016, 96, 133-158. [CrossRef]

129. Hałasa, M.; Maciejewska-Markiewicz, D.; Baśkiewicz-Hałasa, M.; Safranow, K.; Stachowska, E. Post-Delivery Milking Delay Influence on the Effect of Oral Supplementation with Bovine Colostrum as Measured with Intestinal Permeability Test. Medicina 2020, 56, 495. [CrossRef]

130. Davison, G.; Marchbank, T.; March, D.S.; Thatcher, R.; Playford, R.J. Zinc carnosine works with bovine colostrum in truncating heavy exercise-induced increase in gut permeability in healthy volunteers. Am. J. Clin. Nutr. 2016, 104, 526-536. [CrossRef]

131. Playford, R.J.; Garbowsky, M.; Marchbank, T. Pasteurized Chicken Egg Powder Stimulates Proliferation and Migration of AGS, RIE1, and Caco-2 Cells and Reduces NSAID-Induced Injury in Mice and Colitis in Rats. J. Nutr. 2020, 150, 1434-1442. [CrossRef]

132. Gleeson, M. Immunological aspects of sport nutrition. Immunol. Cell Biol. 2016, 94, 117-123. [CrossRef] [PubMed]

133. Rathe, M.; de Pietri, S.; Wehner, P.S.; Frandsen, T.L.; Grell, K.; Schmiegelow, K.; Sangild, P.T.; Husby, S.; Müller, K. Bovine Colostrum Against Chemotherapy-Induced Gastrointestinal Toxicity in Children With Acute Lymphoblastic Leukemia: A Randomized, Double-Blind, Placebo-Controlled Trial. J. Parenter. Enter. Nutr. 2019, 2, 337-347. [CrossRef] [PubMed]

134. Filipescu, I.E.; Leonardi, L.; Menchetti, L.; Guelfi, G.; Traina, G.; Casagrande-Proietti, P.; Piro, F.; Quattrone, A.; Barbato, O.; Brecchia, G. Preventive effects of bovine colostrum supplementation in TNBS-induced colitis in mice. PLoS ONE 2018, 13, e0202929. [CrossRef] [PubMed]

135. Khan, Z.; Macdonald, C.; Wicks, A.C.; Holt, M.P.; Floyd, D.; Ghosh, S.; Wright, N.A.; Playford, R.J. Use of the "nutriceutical", bovine colostrum, for the treatment of distal colitis: Results from an initial study. Aliment. Pharmacol. Ther. 2002, 16, 1917-1922. [CrossRef]

136. Hutton, M.L.; Cunningham, B.A.; Mackin, K.E.; Lyon, S.A.; James, M.L.; Rood, J.I.; Lyras, D. Bovine antibodies targeting primary and recurrent Clostridium difficile disease are a potent antibiotic alternative. Sci. Rep. 2017, 7, 5-9. [CrossRef]

137. Gritz Emily, C.; Bhandari, V. The human neonatal gut microbiome: A brief review. Front. Pediatr. 2015, 3, 17.

138. Sun, J.; Li, Y.; Pan, X.; Nguyen, D.N.; Brunse, A.; Bojesen, A.M.; Rudloff, S.; Mortensen, M.S.; Burrin, D.G.; Sangild, P.T. Human Milk Fortification with Bovine Colostrum Is Superior to Formula-Based Fortifiers to Prevent Gut Dysfunction, Necrotizing Enterocolitis, and Systemic Infection in Preterm Pigs. J. Parenter. Enter. Nutr. 2019, 43, 252-262. [CrossRef]

139. Bierut, T.; Duckworth, L.; Grabowsky, M.; Ordiz, M.I.; Laury, M.L.; Callaghan-Gillespie, M.; Maleta, K.; Manary, M.J. The effect of bovine colostrum/egg supplementation compared with corn/soy flour in young Malawian children: A randomized, controlled clinical trial. Am. J. Clin. Nutr. 2020, nqaa325. [CrossRef]

140. Hałasa, M.; Maciejewska, D.; Baśkiewicz-Hałasa, M.; Machaliński, B.; Safranow, K.; Stachowska, E. Oral Supplementation with Bovine Colostrum Decreases Intestinal Permeability and Stool Concentrations of Zonulin in Athletes. Nutrients 2017, 9, 370. [CrossRef]

141. Cesarone, M.R.; Belcaro, G.; di Renzo, A.; Dugall, M.; Cacchio, M.; Ruffini, I.; Pellegrini, L.; del Boccio, G.; Fano, F.; Ledda, A.; et al. Prevention of influenza episodes with colostrum compared with vaccination in healthy and high-risk cardiovascular subjects: The epidemiologic study in San Valentino. Clin. Appl. Thromb. Hemost. 2007, 13, 130-136. [CrossRef]

142. Patel, K.; Rana, R. Pedimune in recurrent respiratory infection and diarrhoea- The Indian experience-the pride study. Indian J. Pediatr. 2006, 73, 585-591. [CrossRef]

143. Saad, K.; Abo-Elela, M.G.M.; El-Baseer, K.A.A.; Ahmed, A.E.; Ahmad, F.A.; Tawfeek, M.S.K.; El-Houfey, A.A.; Khair, M.D.A.; Abdel-Salam, A.M.; Abo-Elgheit, A.; et al. Effects of bovine colostrum on recurrent respiratory tract infections and diarrhea in children. Medicine 2016, 95, 4-8. [CrossRef]

144. Nederend, M.; van Stigt, A.H.; Jansen, J.H.M.; Jacobino, S.R.; Brugman, S.; de Haan, C.A.M.; Bont, L.J.; van Neerven, R.J.J.; Leusen, J.H.W. Bovine IgG Prevents Experimental Infection With RSV and Facilitates Human T Cell Responses to RSV. Front. Immunol. 2020, 11, 1701. [CrossRef]

145. Jones, A.W.; March, D.S.; Curtis, F.; Bridle, C. Bovine colostrum supplementation and upper respiratory symptoms during exercise training: A systematic review and meta-analysis of randomised controlled trials. BMC Sports Sci. Med. Rehabil. 2016, 8, 21. [CrossRef]

146. Kovacs, D.; Maresca, V.; Flori, E.; Mastrofrancesco, A.; Picardo, M.; Cardinali, G. Bovine colostrum induces the differentiation of human primary keratinocytes. FASEB J. 2020, 34, 1-20. [CrossRef]

147. Hartog, A.; Leenders, I.; van der Kraan, P.M.; Garssen, J. Anti-inflammatory effects of orally ingested lactoferrin and glycine in different zymosan-induced inflammation models: Evidence for synergistic activity. Int. Immunopharmacol. 2007, 7, 1784-1792. [CrossRef]

148. Hong, J.P.; Park, S.W. The combined effect of recombinant human epidermal growth factor and erythropoietin on full-thickness wound healing in diabetic rat model. Int. Wound J. 2014, 11, 373-378. [CrossRef]

149. Griffiths, C.E.M.; Cumberbatch, M.; Tucker, S.C.; Dearman, R.J.; Andrew, S.; Headon, D.R.; Kimber, I. Exogenous topical lactoferrin inhibits allergen-induced Langerhans cell migration and cutaneous inflammation in humans. Br. J. Dermatol. 2001, 144, 715-725. [CrossRef]

150. Lee, J.; Kwon, S.H.; Kim, H.M.; Fahey, S.N.; Knighton, D.R.; Sansom, A. Effect of a growth protein-colostrum fraction* on bone development in juvenile rats. Biosci. Biotechnol. Biochem. 2008, 72, 1-6. [CrossRef]

151. Duff, W.R.D.; Chilibeck, P.D.; Rooke, J.J.; Kaviani, M.; Krentz, J.R.; Haines, D.M. The effect of bovine colostrum supplementation in older adults during resistance training. Int. J. Sport Nutr. Exerc. Metab. 2014, 24, 276-285. [CrossRef] 
152. Hwang, K.A.; Hwang, Y.J.; Ha, W.; Choo, Y.K.; Ko, K. Oral administration of insulin-like growth factor-I from colostral whey reduces blood glucose in streptozotocin-induced diabetic mice. Br. J. Nutr. 2012, 108, 39-45. [CrossRef] [PubMed]

153. Kim, J.H.; Jung, W.S.; Choi, N.J.; Kim, D.O.; Shin, D.H.; Kim, Y.J. Health-promoting effects of bovine colostrum in Type 2 diabetic patients can reduce blood glucose, cholesterol, triglyceride and ketones. J. Nutr. Biochem. 2009, 20, 298-303. [CrossRef] [PubMed]

154. Golay, A.; Ferrara, J.M.; Felber, J.P.; Schneider, H. Cholesterol-lowering effect of skim milk from immunized cows in hypercholesterolemic patients. Am. J. Clin. Nutr. 1990, 52, 1014-1019. [CrossRef] [PubMed]

155. Mizrahi, M.; Shabat, Y.; Ben Ya'acov, A.; Lalazar, G.; Adar, T.; Wong, V.; Muller, B.; Rawlin, G.; Ilan, Y. Alleviation of insulin resistance and liver damage by oral administration of Imm124-E is mediated by increased Tregs and associated with increased serum GLP-1 and adiponectin: Results of a phase I/II clinical trial in NASH. J. Inflamm. Res. 2012, 5, 141-150.

156. Adar, T.; Ben Ya'acov, A.; Lalazar, G.; Lichtenstein, Y.; Nahman, D.; Mizrahi, M.; Wong, V.; Muller, B.; Rawlin, G.; Ilan, Y. Oral administration of immunoglobulin G-enhanced colostrum alleviates insulin resistance and liver injury and is associated with alterations in natural killer T cells. Clin. Exp. Immunol. 2012, 167, 252-260. [CrossRef]

157. Faber, S.N.; Faber, N.E.; Mccauley, T.C.; Ax, R.L. Case Study: Effects of Colostrum Ingestion on Lactational Performance. Profess. Anim. Sci. 2005, 21, 420-425. [CrossRef]

158. Wells, S.J.; Dargatz, D.A.; Ott, S.L. Factors associated with mortality to 21 days of life in dairy heifers in the United States. Prev. Vet. Med. 1996, 29, 9-19. [CrossRef]

159. Boudry, C. Bovine colostrum as a natural growth promoter for newly weaned piglets: A review. Anim. Sci. Biotechnol. 2008, 66, 1-2.

160. King, M.R.; Morel, P.C.H.; Pluske, J.R.; Hendriks, W.H. A comparison of the effects of dietary spray-dried bovine colostrum and animal plasma on growth and intestinal histology in weaner pigs. Livest. Sci. 2008, 119, 167-173. [CrossRef]

161. Huërou-Luron, I.L.; Huguet, A.; Callarec, J.; Leroux, T.; Dividich, J.L. Supplementation of a weaning diet with bovine colostrum increases feed intake and growth of weaned piglets. J. Rech. Porcine France 2004, 36, 33-38.

162. King, M.R.; Ravindran, V.; Morel, P.C.H.; Thomas, D.v.; Birtles, M.J.; Pluske, J.R. Effects of spray-dried colostrum and plasmas on the performance and gut morphology of broiler chickens. Aust. J. Agric. Res. 2005, 56, 811-817. [CrossRef]

163. Parapary, M.H.G.; Nobakht, A.; Mehmannavaz, Y. Co-supplementation of colostrum powder on performance, intestinal morphology, blood biochemical parameters and antioxidant status of broilers in heat stress. Semina Cien. Agrar. 2020, 41, 3419-3427. [CrossRef]

164. Giffard, C.J.; Seino, M.M.; Markwell, P.J.; Bektash, R.M. Benefits of bovine colostrum on fecal quality in recently weaned puppies. J. Nutr. 2004, 134, 2126S-2127S. [CrossRef] [PubMed]

165. Dequenne, M.; Robaye, V.; Dotreppe, O.; Neizer, C.; Delhalle, L.; Thonart, P.; Bertrand, C.; Robert, B.; Moinet, B.; Diez, M. A supplement of bovine colostrum and probiotics increased protein digestibility in dogs but did not influence microbiome. In Proceedings of the 18th Congress of the European Society of Veterinary and Comparative Nutrition, Utrecht, The Netherlands, 11-13 September 2014; Available online: http:/ / hdl.handle.net/2268/200872 (accessed on 1 July 2020).

166. Holmes, M.A.; Lunn, D.P. A study of bovine and equine immunoglobulin levels in pony foals fed bovine colostrum. Equine Vet. J. 1991, 2, 116-118. [CrossRef]

167. Fenger, C.; Tobin, T.; Casey, P.; Langemeier, J.; Haines, D. Bovine colostrum supplementation does not influence serum insulin-like growth factor-1 in horses in race training. J. Equine Vet. Sci. 2014, 34, 1025-1027. [CrossRef] 